Karakitsios V., Roveri M., Lugli S., Manzi V., Gennari R., Antonarakou A., Triantaphyllou M., Agiadi K., Kontakiotis G., Kafousia N., De Rafelis M., 2017. A Record of the Messinian Salinity Crisis in the Eastern Ionian Tectonically Active Domain (Greece, Eastern Mediterranean). Basin Research, 29,203-233. DOI: 10.1111/bre.12173.

\title{
A record of the Messinian salinity crisis in the eastern Ionian tectonically active domain (Greece, eastern Mediterranean)
}

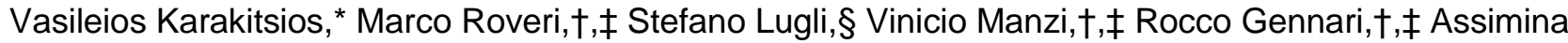 \\ Antonarakou, ${ }^{*}$ Maria Triantaphyllou, ${ }^{*}$ Konstantina Agiadi, ${ }^{*}$ George Kontakiotis, ${ }^{*}$ Nefeli Kafousia* and \\ Marc de Rafelis
}

*Department of Historical Geology and Paleontology, Faculty of Geology and Geoenvironment, National and Kapodistrian University of Athens, Athens, Greece

†Dipartimento di Fisica e Scienze Della Terra, Universit_a degli Studi di Parma, Parma, Italy

$\ddagger A L P$, Alpine Laboratory of Palaeomagnetism, Peveragno, CN, Italy

§Dipartimento di Scienze Chimiche e Geologiche, Universit_a degli Studi di Modena e Reggio Emilia,

Modena

Italy

qUniversité Pierre et Marie Curie, Institut des Sciences de la Terre de Paris UMR 7193 CNRS-UPMC, Paris, France

\begin{abstract}
This integrated study (field observations, micropalaeontology, magnetostratigraphy, geochemistry, borehole data and seismic profiles) of the Messinian-Zanclean deposits on Zakynthos Island (Ionian Sea) focuses on the sedimentary succession recording the pre-evaporitic phase of the Messinian salinity crisis (MSC) through the reestablishment of the marine conditions in a transitional area between the eastern and the western Mediterranean. Two intervals are distinguished through the palaeoenvironmental reconstruction of the pre-evaporitic Messinian in Kalamaki: (a) 6.45-6.122 Ma and (b) 6.122-5.97 Ma. Both the planktonic foraminifer and the fish assemblages indicate a cooling phase punctuated by hypersalinity episodes at around $6.05 \mathrm{Ma}$. Two evaporite units are recognized and associated with the tectonic evolution of the Kalamaki-Argassi area. The Primary Lower Gypsum (PLG) unit was deposited during the first MSC stage (5.971-5.60 Ma) in late-Messinian marginal basins within the pre-Apulian foreland basin and in the wedge-top $(<300 \mathrm{~m}$ ) developed over the Ionian zone. During the second MSC stage (5.60$5.55 \mathrm{Ma}$ ), the PLG evaporites were deeply eroded in the forebulge-backbulge and the wedge-top areas, and supplied the foreland basin's depocentre with gypsum turbidites assigned to the Resedimented Lower Gypsum (RLG) unit. In this study, we propose a simple model for the Neogene-Pliocene continental foreland-directed migration of the Hellenide thrusting, which explains the palaeogeography of the Zakynthos basin. The diapiric movements of the Ionian Triassic evaporites regulated the configuration and the overall subsidence of the foreland basin and, therefore, the MSC expression in this area.
\end{abstract}

\section{INTRODUCTION}

The Messinian salinity crisis (MSC; Selli, 1954), the greatest Mediterranean palaeoenvironmental perturbation, inspired researchers for more than fifty years and still offers a fascinating story tale. Despite the fact that certain aspects were investigated to great extent, major questions remain open (Roveri et al., 2014a). The scope of the present study is to describe, in detail, the Messinian-Zanclean deposits and their inclusive fauna on Zakynthos Island (Ionian Sea), a pivotal area located at the transition between the eastern and the western Mediterranean. The MSC-associated environmental changes are revealed through high-resolution integrated stratigraphy. Furthermore, a tectonosedimentary evolution model is proposed, which incorporates new palaeontologic, sedimentologic, biostratigraphic, palaeomagnetic and geochemical data.

\section{THEMESSINIAN SALINITYCRISIS}

Since the beginning of the Messinian (7.251 Ma), the gradual restriction of the Mediterranean-Atlantic marine connection was combined with long-term orbital forcing (Hilgen et al., 2007) to significantly alter the

palaeoenvironmental conditions in the entire basin, through: (a) a reduction of deep-water ventilation at 7.15 Ma, which isrecorded by diatom-rich and opal-rich sediment deposition between 7.15 and $6.7 \mathrm{Ma}$, (b) a sudden drop in calcareous 
plankton diversity at $6.7 \mathrm{Ma}$, (c) the intensification of bottom-water stagnation and stratification,

(d) carbonate precipitation between 6.3 and 5.97 Ma and (e) the complete disappearance of planktonic foraminifers during summer insolation minima (Sierro et al., 1999, 2003; Kouwenhoven et al., 1999, 2003, 2006; Bellanca et al., 2001; Blanc-Valleron et al., 2002; Kouwenhoven \& van der Zwaan, 2006; van Assen et al., 2006; Manzi et al., 2007, 2011, 2013; Gennari et al., 2013). The MSC started synchronously at 5.97 Ma throughout the basin (Krijgsman et al., 1999a, 2002; Manzi et al., 2013) with primary subaqueous gypsum precipitation (Primary Lower Gypsum; PLG) in shallow-water settings with moderate oxygenation (Lugli et al., 2010) and evaporite-free dolomite and organic-rich shale deposition in intermediate and deeper basins (Manzi et al., 2007, 2011; de Lange \& Krijgsman, 2010; Dela Pierre et al., 2012). The MSC stage 1 (Roveri et al., 2008a, 2014a) continued until ca. 5.6 Ma (Vai, 1997; Krijgsman et al., 1999b; Hilgen et al., 2007; Lugli et al., 2010). During MSC stage 2 (5.6-5.55 Ma; Roveri et al., 2014a), the Messinian Erosional Surface (MES) developed across the Mediterranean margins due to subaerial erosion. In the margins, the tectonic activity and the general slope instability led to the erosion and resedimentation of the PLG and the widespread deposition of clastic evaporites (Resedimented Lower Gypsum; RLG sensu Roveri et al., 2008b) throughout the Mediterranean (e.g. Ricci Lucchi, 1973; Robertson et al., 1995; Fortuin \& Krijgsman, 2003; Roveri et al., 2003; Roveri \& Manzi, 2006; Omodeo-Sale et al., 2012; Lugli et al., 2013; Iadanza et al., 2013; Manzi et al., 2015). The MSC stage 3 (5.55-5.33 Ma; Manzi et al., 2009; Roveri et al., 2014a) was characterized by selenite and cumulate gypsum precipitation in the shallow-water sub-basins (Rouchy, 1982; Roveri et al., 2008a; Manzi et al., 2009, 2015); mostly clastic sediments were deposited in the northern and western Mediterranean. Typical of this stage is the Lago Mare facies (Gignoux, 1936; Ruggieri, 1967; Orszag-Sperber, 2006) indicating surface-water dilution occasionally interrupted by evaporitic events (Upper Gypsum; UG; Manzi et al., 2009). The end of the MSC and the return to full marine conditions took place at 5.33 Ma through a catastrophic flooding event (Hsu et al., 1973; Blanc-Valleron et al., 2002; Meijer \& Krijgsman, 2005; Garcia-Castellanos et al., 2009). The Messinian/Zanclean boundary commonly includes a transitional organic-rich interval (Roveri et al., 1998, 2008b; Gennari et al., 2008), followed by early Pliocene marine deposits ('Trubi' or 'Argille Azzurre' formations).

\section{GEOLOGICAL SETTING}

Western Greece is dominated by the external zones of the Hellenide fold-and-thrust belt, namely the pre-Apulian (or Paxos), the Ionian and the Gavrovo zones (Fig. 1A and inset map of Fig. 2). From the Triassic to the Upper Cretaceous, western Greece was part of the Apulian continental block on the southern passive margin of the Tethys. At a regional scale $(9100 \mathrm{~km})$ the alpine belt can be considered as the margin of the Tethys Ocean, inverted by the collision of Apulia with Europe. On a smaller scale $(910 \mathrm{~km})$, in the Hellenic realm, the subbasins of the Hellenic Tethyan margin were inverted to produce the main Hellenic thrust sheets or folded zones.

This occurred progressively from the innermost (eastern) to the more external (western) zones (Karakitsios, 1995, 2013). The pre-Apulian zone consists of Triassic-Lower Jurassic evaporites, followed by Middle Jurassic to Oligocene deposits, mainly neritic-pelagic carbonates overlain by Neogene and Quaternary marly limestones, marls and sands intercalated by late Miocene evaporitic beds (Karakitsios \& Rigakis, 2007; Karakitsios, 2013). The Ionian zone comprises sedimentary rocks ranging from Triassic evaporites to Jurassic-late Eocene carbonates and minor cherts and shales, which are overlain by an Oligocene flysch (Karakitsios, 1995, 2013). The thrust boundary between the Ionian and pre-Apulian zones is marked by intrusive evaporites (Fig. 1A). This suggests that contraction deformation was the most important structural control on orogenesis in western Greece. Although halokinesis was important along the boundary faults during the Mesozoic extension, thrusting has overprinted the Mesozoic extensional structures to such an extent that the latter are almost impossible to distinguish (Karakitsios \& Rigakis, 2007; Karakitsios, 2013). Field observations of the relationship between the pre-Apulian and Ionian zones emphasize the close association between Hellenide thrusts and folds and areas of evaporite exposure (evaporite dissolution-collapse breccias and gypsum; Karakitsios \& Pomoni-Papaioannou, 1998; Pomoni-Papaioannou et al., 2004), even where the precise location of the thrust is unclear. Evaporites crop out along the leading edges of thrust sheets as well as in the onshore geological section and the offshore seismic profiles (Fig. 1). This location, together with their occurrence in tectonic windows above deformed flysch (observed in many places of Akarnania), suggests that the evaporites represent the lowest detachment level of individual overthrust sheets in the external Hellenides. Furthermore, the absence of pre-evaporitic units from outcrops in western Greece, the great thickness of the evaporites (greater than $3 \mathrm{~km}$ in boreholes in the Ionian zone: IGRS-IFP, 1966; BP, 1971), and theprobable incorporation of Permian basement into the thin-skinned orogenic wedge east of the Pindos thrust all support the idea that the evaporites form a moderate to major d_ecollement level throughout the external Hellenides, rather than widespread diapirism (Underhill, 1989; Karakitsios, 1995, 2013). Thus, the role of the evaporites resembles that in the thin-skinned thrust belts of Western Europe (Karakitsios, 2013). The Zakynthos Island's alpine sequence belongs

(Fig. 2) to the pre-Apulian and partly to the Ionian zone - separated by the Ionian thrust - whose emplacement took place during the early Pliocene (BP, 1971; Sorel, 1976; Nikolaou, 1986; Underhill, 1989; Karakitsios \& Rigakis, 2007). The pre-Apulian zone of Zakynthos comprises Upper Cretaceous to Pleistocene sediments, whereas the Ionian zone is represented by Triassic breccias and microcrystalline gypsum corresponding to the lower stratigraphic unit of this zone. Cretaceous to Oligocene carbonates outcrop on Marathonisi Islet (2.5 km east 
of Keri; Fig. 2) and probably represent a transitional facies between the Ionian and pre-Apulian domains (Nikolaou, 1986). Numerous reverse faults cut the pre- Apulian sequence along the NW-SE direction, exposing late Miocene sandstones and marls along the coastal sections between Agios Sostis and Keri (Fig. 2); these are significantly folded, indicating a post-Miocene age for the Ionian thrust emplacement (Underhill, 1989; Karakitsios, 2013).

The Ionian sequence is unconformably overlain by Neogene and Quaternary deposits outcropping mainly in south-eastern Zakynthos. These are similar to those of the pre-Apulian zone, but thinner and characterized by unconformities (Dermitzakis, 1977; Nikolaou, 1986), and they consist of early Miocene clastic sediments outcropping in the Skopos area, followed by late-Messinian marls and shales (30-100 m thick) intercalated with gypsum (Fabricius et al., 1998). The early Pliocene deposits include calcareous pelagic marls (Trubi limestone) and sandstone intercalations (Kontopoulos et al., 1997). The late Pliocene to Pleistocene deposits comprise a transgressive clastic sequence recording sea-level changes concurrent with intense tectonic movements (Tsapralis, 1981; Triantaphyllou, 1996; Triantaphyllou et al., 1997; Duermeijer et al., 1999; Zelilidis et al., 1998; Agiadi et al., 2010). The average depositional depth in this area exceeded $450 \mathrm{~m}$ during the Pliocene and the early Pleistocene (until 1.66 Ma), gradually diminished to 200- $400 \mathrm{~m}(1.25-0.97 \mathrm{Ma})$, until the final tectonic uplift of the south-eastern part of the island took place certainly after $0.97 \mathrm{Ma}$ (Agiadi et al., 2010).

\section{METHODS}

\section{Field geology, borehole and seismic data}

Field observations were combined with detailed sampling along the Kalamaki-Argassi and Agios Sostis areas in the south-eastern part of Zakynthos Island. A main concern was to distinguish the Ionian zone Triassic gypsum from the Messinian gypsum, both expressed in this area. The Ionian thrust's cartographic position and the Neogene deposits' distribution were based on new tectonic, stratigraphic and sedimentologic observations, in conjunction with a reinterpretation of the available borehole and onshore seismic data.

\section{Planktonic Foraminifera}

In the Kalamaki and Agios Sostis sections, 198 samples were collected. In the Kalamaki section, 175 samples were obtained at 0.05- to 0.50-m intervals in the west (pre- MSC) and the east subsection (Messinian-Zanclean), representing $37.1 \mathrm{~m}$ of sediment thickness (Fig. 3). In the Agios Sostis section, 23 samples were collected at 0.05- to 1-m intervals for a total thickness of $20 \mathrm{~m}$. Fourteen samples (AS 1-14) were studied from the $16.5 \mathrm{~m}$ of the pre-evaporitic sequence (sampling step about 0.30 to $1 \mathrm{~m}$ ), and nine samples were examined from the $20 \mathrm{~m}$ of the post-evaporitic sequence. Three samples (AS 15-17) were obtained from the first $1.20 \mathrm{~m}$ of the post-evaporitic sequence, which are rich in gypsum crystals, six samples (AS 18-23) were taken from the last $1.5 \mathrm{~m}$ of the Agios Sostis section (Fig. 4). The samples were washed through a 63-lm sieve. Planktonic foraminifer biostratigraphy was based on the presence of index species, their abundance, and the coiling ratio of Neogloboquadrina acostaensis. The bioevents were determined on the planktonic foraminifer assemblage observed in the fraction larger than $125 \mathrm{~lm}$, following the biozonal scheme of Iaccarino et al. (2007) and through correlation with astronomically calibrated successions of the Mediterranean area (Krijgsman et al., 1999b; Sierro et al., 2001; Iaccarino et al., 1999; Gennari et al., 2008). The palaeoecological remarks were based on the qualitative and semiquantitative analysis of the assemblage with respect to the identified species' modern ecological affinities (B_e \& Tolderlund, 1971; Hemleben et al., 1989).

\section{Calcareous nannofossils}

Smear slides were prepared following the standard technique described by Perch Nielsen (1985) and Bown \& Young (1998). The taxonomy of the determined calcareous nannofossil species was in accordance with Aubry (1984, 1988, 1989, 1990, and 1999) and Perch Nielsen (1985). The biostratigraphic analysis was based on the standard biozonal scheme of Martini (1971). The biochronology and the numerical ages of the biozone boundaries were assigned according to Lourens et al. (2004), Raffi et al. (2006) and Backman et al. (2012). The nannofossil biostratigraphy incorporated qualitative and semiquantitative analyses. Qualitative methods are traditionally based on the estimation of index-species presences, obtained through a rough scan of the sample. Concerning semiquantitative methods, these were mainly used to overcome the very terrigenous and relatively shallow nature of the studied samples, in which nannofossils are rather scarce. To obtain accurate biostratigraphic estimations, at least 100 fields of view were investigated per slide, using a Leica DMLSP optical polarizing light microscope at 12509 magnification. The identified taxa were categorized based on their semiquantitative abundances as follows: A, abundant, more than one specimen in every field of view; C, common, one specimen in every ten fields of view; R, rare, one specimen in every 50 fields of view; P, present, one specimen in more than 100 fields of view; and RW, reworked specimens. The biostratigraphic framework for the Trubi deposits

was based on the palaeoecological affinities of the following calcareous nannofossil species. Small Gephyrocapsa spp. $<3 \mathrm{~lm}$, are considered upper photic-zone opportunistic taxa, indicating eutrophic conditions (e.g. Flores et al., 2005). Discoasterids, generally preferring warm and oligotrophic waters, are lower photic-zone inhabitants, which 
increase their abundance with deep pycnocline (Flores et al., 2005). Helicosphaera carteri is commonly found in warm waters (e.g. Baumann et al., 2005), associated with moderately elevated nutrient levels (e.g. Ziveri et al., 2004). It is commonly accepted as a species tolerant of low salinities and high terrigenous input (Triantaphyllou et al., 2009a,b); it is highly frequent in regions influenced by riverine discharge (e.g. Cros, 2001), as a coastal-water taxon (e.g. Dimiza et al., 2014). In addition, Rhabdosphaeraceae prefer warm and oligotrophic waters (Dimiza et al., 2008; Malinverno et al., 2009) and Scyphosphaera spp. are common in tropical-subtropical regions (Rade, 1975).

\section{Fish otoliths}

The same samples collected for the biostratigraphic analysis were also examined for the fish otolith content. In addition, several $25 \mathrm{~kg}$ bulk samples were obtained throughout the pre-evaporitic interval and the upper part (Trubi Formation) of Kalamaki section, as well as from each of the marl beds alternating with the gypsum (Fig. 3). The aims were (1) to identify the fish fauna in the area before, during and after the MSC; (2) to determine the timing of the reestablishment of a purely marine fauna after the crisis (Carnevale et al., 2006); and (3) to estimate the palaeoenvironmental conditions especially just before the onset of evaporite deposition. Fish otoliths were described according to the criteria set by Nolf (1985) and systematically identified based on the scheme of Nelson (2006). The methodology of Nolf \& Brzobohaty (1994), as readjusted by Agiadi et al. (2010), was applied to estimate the palaeodepth. The palaeoecological analysis was based on the fish's present-day distribution and ecological data acquired through the FishBase database (Froese \& Pauly, 2014).

\section{Magnetostratigraphy}

The magnetostratigraphy of the Kalamaki section was based on a subset of the same samples used for biostratigraphy, 61 samples in total (Figs 3 and 5). Core samples were obtained with a water-cooled diamond-head corer installed on an electric driller. The standard specimens were thermally demagnetized in an ASC oven and the natural remanent magnetization (NRM) was measured on a 2G-Enterprises DC SQUIDS cryogenic magnetometer, in a magnetically shielded room at the ALP Laboratory of Peveragno (Italy). Samples were first heated at $90^{\circ} \mathrm{C}$, and then, successive $30^{\circ} \mathrm{C}$ steps were applied up to a maximum of $560^{\circ} \mathrm{C}$. The magnetic susceptibility was monitored during heating to detect mineralogical changes. The NRM data set was processed using the Remasoft software (Chadima \& Hrouda, 2006) to calculate the direction of the characteristic remanent magnetization (ChRM) and the virtual geomagnetic pole (VGP) for each sample.

\section{Oxygen and carbon stable isotopes}

One hundred and six (106) bulk rock samples from the pre-evaporitic and 26 samples from the post-evaporitic sequence were analysed in terms of oxygen ( $\left.\mathrm{d}_{18} \mathrm{O}_{\mathrm{carb}}\right)$ and carbon $\left(\mathrm{d}_{13} \mathrm{C}_{\mathrm{carb}}\right)$ stable isotopes (Fig. 6). Moreover, stable isotopes were additional analysed on 45 samples from pre-evaporitic and 37 samples from the post-evaporitic sequence on a combination of species (Turborotalita multiloba and Orbulina universa for the Miocene;

Globigerinoides obliquus for the Pliocene) depending on their availability.More explicitly, the isotopic analyses were performed on: T. multiloba ( $\mathrm{d}_{18} \mathrm{O}_{\text {T.multiloba. }} \mathrm{d}_{13} \mathrm{C}_{\text {. universa }}$ ) shells on samples from the base of the section $(0-7 \mathrm{~m}), \mathrm{O}$. universa ( $\mathrm{d}_{18} \mathrm{O}_{\text {o.universa. }} \mathrm{d}_{13} \mathrm{C}$.multiloba) shells for the remaining of the Messinian pre-evaporitic interval (9.6$19.5 \mathrm{~m}$ ), and G. obliquus ( $\left.\mathrm{d}_{18} \mathrm{O}_{\text {G.obliquus. }} \mathrm{d}_{13} \mathrm{C}_{\mathrm{G} . o b l i q u u s}\right)$ shells for the Pliocene Trubi Formation (_15 m thick). The isotopic composition of bulk sediments and planktonic foraminifers, in combination with the all the other data presented here, focused on investigating the environmental conditions before the commencement of evaporite deposition, as well as the system inertia after the MSC. Both bulk samples and foraminifers were analysed to test whether and/or how the fauna responded to the environmental changes as these were imprinted in the sediment. The $\mathrm{d}_{18} \mathrm{O}$ results from the bulk sediment and the foraminifera were comparable in the pre-evaporitic sequence. Therefore, they can be used interchangeably. The lower part of the post-evaporitic sequence (Lago Mare facies) was barren of foraminifera. Consequently, only bulk sediment isotopic analysis was possible. On the other hand, the Trubi sediments were very rich in foraminifera, which were used for the isotopic analysis. The measurements on the bulk samples were conducted with a mass spectrometer VG SIRA 9, whereas a KIEL-IV carbonate device coupled online to a Delta V Advantage IRMS (Thermo Scientific) was used for the isotopic analyses on the planktonic foraminifers. The $\mathrm{CO}_{2}$ extraction was attained through reaction of powder samples (50-100 mg) with anhydrous orthophosphoric acid, at $50^{\circ} \mathrm{C}$. The values were expressed in per mil relative to the Vienna PDB (V-PDB) standard reference. Long-term analytical precision reached $\_0.1 \&$ for $\mathrm{d}_{18} \mathrm{O}_{\text {carb }}, \ldots .05 \&$ for $\mathrm{d}_{13} \mathrm{C}_{\text {carb }},{ }_{-} 0.08 \&$ for $\mathrm{d}_{18} \mathrm{O}$ o.universa and $\mathrm{d}_{18} \mathrm{O}_{\mathrm{G} . o b l i q u u s}$, and _0.05\& for $\mathrm{d}_{13} \mathrm{C}$.universa and $\mathrm{d}_{13} \mathrm{C}_{\mathrm{G} . \text {.obliquus. }}$

\section{Strontium isotopes}

Two gypsum samples (Fig. 3) were analysed for strontium isotope content to distinguish the stage 1 PLG deposits from the stage 3 UG (Flecker et al., 2002; Roveri et al., 2014b). Strontium isotope analyses were carried out at the Scottish Universities Environmental Research Centre in East Kilbride, Scotland (SUERC). Samples were leached in $1 \mathrm{~m}$ ammonium acetate prior to acid digestion with $\mathrm{HNO}_{3}$. Strontium was separated using Eichrom Sr Spec resin. Matrix elements were eluted in 8 м НNO 3 and 3 м $\mathrm{HNO}_{3}$, before elution of $\mathrm{Sr}$ in $0.01 \mathrm{~m}$ 
$\mathrm{HNO}_{3}$. The total procedure blanks for Sr samples prepared using this method was b200 pg. In preparation for mass spectrometry, Sr samples were loaded onto single Re filaments with a Ta-activator similar to that described by Birck (1986). Sr samples were analysed with a VG Sector 54-30 multiple collector mass spectrometer. A $88 \mathrm{Sr}$ intensity of 1V (1_A 10-11A) _ 10\% was maintained. The $87 \mathrm{Sr} / 86 \mathrm{Sr}$ ratio was corrected for mass fractionation using ${ }_{86} \mathrm{Sr} / 88 \mathrm{Sr}=0.1194$ and an exponential law. The mass spectrometer was operated in the peak-jumping mode, with data collected as 15 blocks of 10 ratios providing an internal uncertainty of b0.000020 (2 S.E.). For this instrument NIST SRM 987 gave 0.710249 _ 0.000008 (1 S.D., $\mathrm{n}=17$ ) during the course of the present study.

\section{RESULTS}

\section{Field observations}

Kalamaki-Argassi area The Neogene sequence of the Kalamaki-Argassi area (Fig. 2) lies unconformably over the Ionian zone basement. In the Kalamaki area, the lower $14.5 \mathrm{~m}$ consist of alternating massive and laminated marls with rare calcareous marl and calcarenite intercalations. Bivalves, Discospirina, pteropods, echinoids and molluscs are observed from 5 to $13 \mathrm{~m}$, whereas some slumps and chaotic horizons occur between 14.5 and $17.5 \mathrm{~m}$. The rest of the pre-evaporitic sequence is partially covered by Quaternary detritus (Fig. 7a).

The previous unit is conformably followed by a 108-mthick evaporite succession in the Kalamaki area (Figs 3 and 8). The base of this succession is partially covered by Quaternary debris, which conceals the shales' cyclicity below the first selenite bed. Eight gypsum-marl cycles are identified (A to H), exhibiting different gypsum depositional facies: massive, massive stratified, banded, laminate and branching selenite (Lugli et al., 2010). Thin gypsrudite and gypsarenite intercalations appear in the upper one-third of the succession (Figs 7c-f, and 8) and may be related to the occurrence of small irregular floods entering in the evaporitic basin. These evaporitic facies and their conformable superposition on the pre-MSC succession allow ascribing them to the Primary Lower Gypsum unit (PLG; Roveri et al., 2008a), which accumulated under precessional control during the MSC stage 1 (5.971-5.60; CIESM, 2008; Manzi et al., 2013). Unfortunately, the lack of good exposure at the base of the gypsum does not allow a bed-to-bed correlation with the PLG reference sections. The uppermost eight metres above the PLG succession are terrigenous deposits, comprising laminated greenish marls; interrupted, after the fourth metre of the succession, by a dm-thick gypsarenite bed (cycle $\mathrm{H}$ of depositional gypsum type; Fig. 3). These sediments originated from the hanging wall of a small normal fault separating the lower from the uppermost part of the succession. There are no important facies changes, erosional, or angular discordance in the lower boundary of this succession. In this section, reworked evaporites are present also in association with the primary facies. Therefore, this portion can be included in the PLG unit. In the Argassi area (Fig. 2), only the evaporitic unit was described. The PLG unit (Fig. 9a,b) comprises eight gypsum-marl cycles that can be correlated with those of the Kalamaki section (Fig. 10). However, in the Argassi area, it is not possible to observe the stratigraphic transition of the evaporitic succession to the overlying and the underlying formations, due to tectonics and the Quaternary debris cover. The uppermost part of the gypsum unit in the Kalamaki area is capped by an angular unconformity (Fig. 7b) that can be correlated with the MES and marks the passage to the post-evaporitic unit (CIESM, 2008; Roveri et al., 2014a). The unconformity is sealed by a four-m thick unit consisting of alternating greenish and discontinuous calcareous marl beds, which conformably pass upward to a dark bed and to the Pliocene deposits of the Trubi Formation. The latter begins with three metres whitish massive marly limestones, overlain by an alternation of decametric marly limestones and laminated marl beds. The Trubi Formation can be subdivided into nine lithological cycles (Figs 7b and 11) corresponding to laminated marls and massive 'trubi-like' whitish carbonate couplets. Agios Sostis area The Neogene succession of Agios Sostis area lies over the pre-Apulian zone sequence. The lowermost part of the pre-evaporitic unit consists of decametre-thick shale and sandstone alternations, exhibiting upward decrease in clastic input (Figs 4 and 9c). These deposits are overlain by $3.5 \mathrm{~m}$ of thin sandstone beds with marl intercalations, which in turn are capped by $3 \mathrm{~m}$ of laminated green shale and marl alternations.

In the Agios Sostis area, two parallel linear gypsum outcrops are observed, the Ploumari outcrop and the Panagia (Machairado) outcrop (Fig. 2). The western outcrop (Ploumari) consists of primary bottom-growth selenite (PLG) deposited in shallow-water settings (less than $200 \mathrm{~m}$; Lugli et al., 2010) and is exposed for about three $\mathrm{km}$. The PLG succession is here incomplete and represented only by one or two gypsum beds consisting of very large crystals that are typically found in the two lowermost PLG cycles (Lugli et al., 2010).

Conversely, clastic gypsum deposits that derive from the resedimentation of older PLG deposits mainly characterize the eastern outcrop (Panagia). Moving from Panagia to Agios Sostis in a NNW-SSE direction (Fig. 2), we observe a down-slope transition of different gravity-flow deposits: from chaotic deposits including dm-thick resedimented gypsum blocks to gypsum turbidites alternated with primary gypsum cumulate. These deposits are well exposed in the Agios Sostis section.

This suite of evaporite-bearing gravity-flow deposits suggests that the Panagia sediments derived from the erosion of PLG located to the west, like those outcropping in Ploumari. Unfortunately, we could not observe the preevaporitic/ evaporitic transition in this sector. Thus, it cannot be excluded that the PLG deposits are actually blocks that slid downslope from a more western position. 
Westward, these PLG deposits were completely eroded during the late Messinian, as indicated by the angular unconformity between the early Pliocene conglomerates- sandstones and the early-middle Miocene marls, which was first observed by Nikolaou (1986) in the Perlakia area (about one km north of the Keri village; Fig. 2). Along the Agios Sostis shoreline, a 16-m-thick gypsum unit lies above an erosional or sliding surface developed on top of the pre-evaporitic succession (Figs 4 and 9c). It onsists of several alternations of primary (cumulate) and clastic gypsum (gypsrudite, gypsarenite and gypsiltite; Figs 4 and 9d, f), commonly showing high-angle cross and convolute lamination (Figs 4 and 9e). This successionis mostly characterized by clastic gypsum deposits without the in situ shallow-water selenite, which is found in the Kalamaki-Argassi area. The Agios Sostis exposed evaporite corresponds to a mass flow, which slid from the west to the east, following the dipping of the slope between the forebulge and the foredeep of the Alikanassin. Therefore, the Agios Sostis evaporitic unit can only derive from the dismantlement and resedimentation of the western PLG deposits. Thus, it is ascribed to the RLG unit, which was deposited during the 2nd stage of the salinity crisis (5.60-5.55; CIESM, 2008; Roveri et al., 2008a). The siliciclastic component increases upward in the RLG succession, which is divided into four units; each unit is topped by a centimetre-thick marl bed. Approximately two metres of hybrid sandstones are capping the clastic evaporite unit. The presence of the urban fabric of Agios Sostis Community (harbour) hinders further observations. Nevertheless, the section's continuity is observed in the Agios Sostis islet (Fig. 2), which is separated from the main coastal section by a fault; the two sections are located approximately $130 \mathrm{~m}$ apart. In this islet, about eleven metres of interbedded graded sandstones and marls are observed (level 6 of Fig. 4), exhibiting an upward decrease in siliciclastic material. At approximately 37-38 m above the base of the Agios Sostis composite section, a normal fault with a throw of about two metres is observed (lower level 6 of Fig. 4). The last seven metres of the section (levels $46-53 \mathrm{~m}$ ) are well observed in the rocky elevation of the Agios Sostis harbour, some 130 metres NNW of the islet (upper level 6 and level 7 of Fig. 4). They comprise a six-m-thick succession of graded sandstone and marl alternations, followed by $1.5 \mathrm{~m}$ of whitish marls belonging to the postevaporitic Trubi Formation.

\section{Borehole and seismic reflection data}

Correlation of the available borehole logs (Fig. 12) over the pre-Apulian basement does not provide a clear idea about the thickness distribution of the Neogene sediments of the Zakynthos (Alikanas) basin. The Neogene sediment thickness ranges from $800 \mathrm{~m}$, in the west, to $1350 \mathrm{~m}$, in the east, but there are no stratigraphic layers in the well logs, which could be used as stratigraphic datums (marker beds) to recognize the thickness distribution. Indeed, apart from the western borehole (Kb101), the other boreholes, towards the east, do not penetrate the entire Neogene sequence, and yet the boreholes do not begin from the same stratigraphic level. Only the two western logs allow observing the reduced thickness of the lower Miocene sequence (Kb101) and its gradual thickening towards the immediately eastern $\log (\mathrm{Z} 2)$. Nevertheless, the Zakynthos (Alikanas) basin onshore seismic profile performed in the eastern half of this basin (Figs 2 and 13) shows clearly the eastward thickening of the MiocenePliocene sequence (Messinian gypsum included) towards the depocentre of the basin. Furthermore, the seismic profile suggests that the Ionian thrust is located west of the western Ionian Triassic diapir (Agia Dynati diapir; Fig. 2), more to the west than previously considered. In addition, in the Agios Kyrikos-1 well (Fig. 12; AK1), at the Alikanas basin's depocentre, an increase in the salinity of the drilling mud was recorded, when the drilling penetrated the Messinian evaporites. This fact, combined with the observation of a simultaneous speed reversal of the seismic waves at the same stratigraphic level (C. Nikolaou, pers. comm., 1986), is an indirect indication of the presence of halite in the Messinian evaporitic unit at the basin's depocentre zone.

\section{Planktonic Foraminifera}

Kalamaki section

The abundance of planktonic foraminifers varies throughout the section. In the pre-evaporitic sequence, several samples are barren (KAL 16, 17, 19, 33, 34, 53, 82, 88, 92-94, 96, 97, 19, 110, 118, 123-130, 136-139) or contain only benthic foraminifers (KAL 13, 30, 32, 36-38, 47, 48, 50-52, 103). The preservation is generally good in the lower part of the section, up to $14 \mathrm{~m}$ from the base, and it becomes moderate upward. Planktonic foraminifers within the Trubi Formation are very abundant and well preserved.

In the pre-evaporitic part of the Kalamaki section (Fig. 3), the following species are identified: Turborotalita multiloba, Turborotalita quinqueloba, Globigerinita glutinata, Globigerina bulloides, Globigerina obesa, Orbulina universa, Neogloboquadrina acostaensis (dextral and sinistral forms) and Globorotalia scitula. In the lowermost two metres of the section, Turborotalita multiloba (0.6-7.2 m; samples KAL5-41) is the only species present (0-2 m, KAL7-10) or occur together with rare specimens of Globigerinoides spp., O. universa and T. quinqueloba. A paracme interval, within its abundance distribution, is recognized between 1.95 and 4.3 m (KAL 11-KAL 23), where the species is very rare or absent. The paracme end of this interval (bioevent 3a, Fig. 14) is also recognized in Sorbas Basin, in the upper part of cycle UA23, and in Caltanissetta Basin, just above the influx of G. scitula (Manzi et al., 2011, 2013). The distribution of T. multiloba is similar in Kalamaki and Falconara sections and is probably related to the palaeoecological requirements of the species and the basin's configuration during this period. Above the paracme end, T. multiloba becomes the main planktonic foraminifera faunal component up to $7.2 \mathrm{~m}$, 
although its distribution is discontinuous upward, as it exhibits only two significant peaks at 9 and $10.5 \mathrm{~m}$ (KAL 56 and KAL 64) corresponding to its highest abundance. Turborotalita quinqueloba and G. glutinata are rare in the lower part of the section and dominate the assemblages, in the thick massive marl interval from 7 to 8.5 m (KAL 39 through KAL 49). Neogloboquadrina acostaensis is generally rare in the section, displaying a relative abundance fluctuation between sinistral and dextral specimens. Sinistral forms are more abundant from the base up to $1.5 \mathrm{~m}$ (KAL 9), whereas dextral representatives are prevalent in the 2.7- to 8.4-m interval (KAL 15-KAL 49). Sinistral forms prevail again in the interval between 8.8 and 9.2 m (KAL 54-KAL 57; 60-70\%) and at 10.5 m (KAL 64; $40 \%$ ). Globorotalia scitula is present with two short influxes at 3.7 and $9.3 \mathrm{~m}$ (KAL 20 and KAL 58), between the two peaks of T. multiloba (KAL 56 and 64). The upper part of the section, from $10.5 \mathrm{~m}$ until just below the slumped interval (KAL 65-89), is characterized by the dominance of O. universa, G. bulloides and G. obesa, which reach their maximum abundance in sample KAL $89(14.3 \mathrm{~m})$. Above the slumped interval, planktonic foraminifera are rare to absent up to sample KAL 105, where few representatives of N. acostaensis and Globigerinoides sp. are present. Benthic foraminifera are very abundant in the samples below the first gypsum.

The upper part of the PLG succession in the Kalamaki section (gypsum cycle H; Figs 3, 7b and 8) is characterized by the sporadic presence of the planktonic foraminifera, presented a reworked assemblage: Globoturborotalita nepenthes, Globigerinoides, G. bulloides, Sphaeroidinellopsisc spp. and O. universa. It is followed by the Lago Mare unit, which is characterized by the scattered presence of Sphaeroidinellopsis spp., G. nepenthes and N. acostaensis, mostly reworked. Just below Trubi Formation (KAL 134) the planktonic foraminifer assemblage is well diversified mainly containing Sphaeroidinellopsis, G. obliquus, O. universa and N. acostaensis dextral specimens. Planktonic foraminifers become continuously abundant and well preserved from the base of the Trubi Formation upward (Figs 3, 7b and 11); they are mainly represented by Sphaeroidinellopsis spp., G. obliquus, N. acostaensis (dextral and sinistral), Globorotalia margaritae, G. bulloides and O. universa. Neogloboquadrina acostaensis sinistralcoiling specimens exhibit two influxes in samples KAL 142 and KAL 149. Sphaeroidinellopsis spp. show an acme interval from KAL 147 through KAL 160. Globorotalia margaritae first commonly occurs in KAL 171. Agios Sostis section The samples from the pre-evaporitic sediments of Agios Sostis coastal section are barren of foraminifera. The complete sequence is characterized by the presence of gypsum crystals, possibly of diagenetic origin; gypsum was also recovered from the sieved residual. The lower $1.2 \mathrm{~m}$ of the post-evaporitic sequence, in the coastal elevation of Agios Sostis harbour, are barren of foraminifera, whereas the uppermost $1.5 \mathrm{~m}$ contains a rich planktonic fauna. Samples AS 18 and 19 yield specimens of Globorotalia conomiozea (Fig. 4). This species disappeared from Mediterranean during the pre-evaporitic phase of the MSC, at 6.52 Ma (Krijgsman et al., 1999a, b; Sierro et al., 2001). Therefore, its presence in the postevaporitic sequence of Agios Sostis may be assumed due to reworking. The last four samples of the section (AS 20-23), collected one metre below the Trubi Formation, are characterized by the presence of G. obliquus, G. trilobus, G. decoraperta, G. nepenthes, G. bulloides, G. falconensis, T. quinqueloba, Orbulina sp., Sphaeroidinellopsis spp. and N. acostaensis.

\section{Calcareous nannoplankton - Kalamaki section}

The lower part of the Kalamaki sequence (KAL 10-50) features an abundant nannofossil assemblage in good preservation state (Fig. 3). The prevailing species are Helicosphaera carteri, Calcidiscus leptoporus, Umbilicosphaera jafari and small Reticulofenestra spp. (R. haqii, R. minutula). Six-rayed discoasters are very rare, and Discoaster quinqueramus is practically absent. Nearly monospecific assemblages of Sphenolithus abies are observed upward. The upper part of the sequence is characterized by the sporadic presence of Amaurolithus delicatus, A. primus, A. tricorniculatus and rare Nicklithus amplificus. The upper part of the PLG in Kalamaki section (KAL 114-125; Fig. 3) is characterized by intense reworking and contains rare nannofossil specimens, in bad preservation, mostly reworked assemblages of Oligocene-Miocene age also including Cretaceous taxa.

The Lago Mare facies unit (KAL 120-134), beneath the Trubi Formation of Kalamaki section (Fig. 3), displays rare to common well-preserved small Gephyrocapsa spp. coccoliths $(1.5-3.0 \mathrm{~lm})$ within a rich but reworked assemblage. Just below the Trubi Formation (KAL 134), the rare presence of Ceratolithus acutus together with specimens of Reticulofenestra zancleana is recorded.

\section{Fish remains}

Sixteen fish taxa are identified in the pre-evaporitic sediments of Kalamaki section based on the otolith remains (Table 1; Fig. 15). The samples obtained from the marls in between the evaporites, as well as from the upper part of Kalamaki section, including the Trubi Formation, did not yield otolith remains. The Kalamaki pre-evaporitic teleost fauna resembles those identified by Girone et al.(2010) in the pre-evaporitic successions of northern Italy. Indeed the great diversity of the benthic-benthopelagic group is asserted here as well. Gadiculus labiatus is the most frequent benthic species in the assemblages, although the overall abundance of gobiids is higher. However, the gobiid specimens are very small and indeterminable to the specific, or even generic, level. The pelagic realm is dominated by myctophids, particularly those belonging to the genus Diaphus, which is much diversified; five different species are identified, with high abundance in the studied samples. Notably, Diaphus rubus and Myctophum coppa, two fossil species first reported by Girone et al. (2010) in the pre-evaporitic sequence of northern Italy, are also found in pre-evaporitic succession of Kalamaki section (samples KAL 6, KAL 13, KAL 15, KAL 26, 
KAL 27, KAL 31, KAL 41, KAL 81, KAL 87, KAL 89, KAL 95). In biogeographic terms, six of the fourteen fish, identified at the specific level, are extinct today; the remaining still inhabit the Mediterranean Sea,

apart from Physiculus huloti, which occurs only in the Atlantic Ocean (Cohen et al., 1990). Diaphus cf. pedemontanus, D. rubus and Myctophum coppa are absent in the so far studied Pliocene and Pleistocene assemblages of the eastern Mediterranean (Agiadi et al., 2011, 2013; Agiadi, 2013).

During the time interval preceding the onset of the MSC, the Kalamaki area presents a well-diversified fish fauna, comprising both abundant pelagic and benthic-benthopelagic fish. The continuous presence of gobiids throughout the basal part of the section and the occurrence of Buglossidium sp. in sample KAL 31 suggest rather shallow-water depths before the onset of gypsum deposition. In fact, the occurrence of benthopelagic Physiculus aff. huloti (bulk sample KAL base) indicates depths less than $320 \mathrm{~m}$ (OBIS, 2006). However, the great diversity and abundance of the genus Diaphus and the presence of gadids (Gadiculus argenteus and Gadiculus labiatus) in the upper part of the basal sequence (just prior to the gypsum deposits, samples KAL 27, KAL 28, KAL 38, KAL 39, KAL 45), suggest the area was not secluded, and depths certainly greater than $50 \mathrm{~m}$ may be expected. In addition, Maurolicus muelleri is present in almost all the samples examined and in great abundances. Although this bathypelagic species has a large bathymetric distribution today, between 0 and $1524 \mathrm{~m}$ according to Wheeler (1992), it is usually found between 300 and $400 \mathrm{~m}$ depth (Mauchilne, 1988). Combining the above results, the palaeodepth is estimated up to $300 \mathrm{~m}$ for the basal sequence of Kalamaki section. Considering the modern ecological data for the extant species present in the Kalamaki fish assemblage (Table 1), as well as the high occurrence of the extinct Mediterranean species Diaphus cavallonis, D. rubus, D. cf. pedemontanus, Myctophum coppa and Gadiculus labiatus, which are typically recorded in the Miocene and Pliocene (Carnevale et al., 2008; Girone et al., 2010; Agiadi et al., 2013), the Kalamaki area was probably situated on the tropical-subtropical climatic zone border. Significant, in this respect, are the occurrences of tropical present-day extra-Mediterranean species Physiculus aff. huloti and Diaphus taaningi.

\section{Magnetostratigraphy}

The thermal demagnetization patterns and the trend of the magnetic susceptibility with increasing temperature clearly show two different behaviours in the pre-evaporitic unit and in the Trubi Formation of Kalamaki section (Fig. 3). The demagnetization patterns of both groups indicate that a low-temperature component, probably of viscous origin, is sometimes demagnetized at $120^{\circ} \mathrm{C}$. A second, normally oriented component is demagnetized up to $210-330^{\circ} \mathrm{C}$; it generally contributes with $70-80 \%$ to the initial magnetization in the pre-evaporitic interval and with 50-70\% in the Trubi Formation. This component is interpreted as an overprint of the present-day field; in fact, in geographic coordinates, its mean declination is $0.7^{\circ} \mathrm{N}$ and the inclination is $54.5^{\circ}$ $\left(\mathrm{N}=52 ; \mathrm{A} 95=2.7^{\circ}\right)$, which are values very close tothe present-day field direction in the area of Zakynthos $\left(3.79^{\circ} \mathrm{N}\right.$ of declination and $54.05^{\circ}$ of inclination). Samples collected in the pre-evaporitic sequence have a weak magnetization, showing a mean normal remanent magnetization (NRM) of $4.07 \mathrm{E}-04 \mathrm{~A} / \mathrm{m}$ (with a standard deviation of $6.02 \mathrm{E}-04)$. Usually, an abrupt increase in magnetic susceptibility to $350-420^{\circ} \mathrm{C}$ is detected, concomitant with an increase of the remanent magnetization, both indicative of authigenic sulphides. Besides the low-temperature components, a higher temperature component is rarely isolated in this group above $210^{\circ} \mathrm{C}$. In several samples, the characteristic component (ChRM) is isolated between 230 and $350^{\circ} \mathrm{C}$. This component exhibits both normal and reversed polarities (Fig. 5). Normal polarities are identified in the following intervals: (a) from the base of the section to $0.6 \mathrm{~m}$, the Zijderveld diagrams for this samples display a linear decay towards the origin; (b) at $2.55 \mathrm{~m}$; (c) from 8.58 to $12.03 \mathrm{~m}$. Sample with reversed polarities are identified at $6.53 \mathrm{~m}$, at $14.02 \mathrm{~m}$ and at $20.15 \mathrm{~m}$. The Zijderveld diagrams of interval (b) and (c) and of reversed polarity samples all show a cluster of demagnetization steps. Mean direction for normal and reversal polarities were calculated by mean of Fisher's statistics and are $64.3^{\circ} / 39.8^{\circ}\left(\mathrm{N}=12, \mathrm{k}=21.6^{\circ}\right.$ and $\left.\mathrm{a} 95=9.6^{\circ}\right)$ and $230.1^{\circ} 50.0^{\circ}\left(\mathrm{N}=4, \mathrm{k}=13.9^{\circ}\right.$ and a95 $\left.=25.6^{\circ}\right)$.

The second group of samples, collected in the Trubi section, displays a higher mean NRM (2.25 E-03 A/m, with a standard deviation of $1.92 \mathrm{E}-03)$. Here, the demagnetization patterns show much more stable trends with respect to the pre-evaporitic samples. The ChRM is successfully recognized in all the samples between 210 and $230^{\circ} \mathrm{C}$ and a maximum of $560^{\circ} \mathrm{C}$. Both reversed (KAL 142 to KAL $154 ; 194.3^{\circ} \% 64.7^{\circ}, \mathrm{N}=5$, $\mathrm{k}=9.17$ and $\left.\mathrm{a} 95=26.7^{\circ}\right)$ and normal $\left(\mathrm{KAL} 156\right.$ to $\mathrm{KAL} 174 ; 39.5^{\circ} / 42.2^{\circ}, \mathrm{N}=15, \mathrm{k}=38.8$ and a95 $\left.=6.2^{\circ}\right)$ polarities are recognized and the reversal is identified between 9.6 and $10.4 \mathrm{~m}$.

\section{Stable oxygen and carbon isotopes}

In the pre-evaporitic sequence of Kalamaki section, bulk sediment and planktonic foraminifer (including both species analysed) d values vary widely $\left(2.71<\mathrm{d}_{18} \mathrm{O}_{\text {carb } \&<7.45 ;} \_.32<\mathrm{d}_{13} \mathrm{C}_{\text {carb }} \&<1.94 ; \_1.44<\mathrm{d}_{18} \mathrm{O}_{\text {foram }} \&<3.73\right.$; $2.90<\mathrm{d}_{13} \mathrm{C}_{\text {foram }}$ $\&<0.95$ ), with heavier values measured in the massive and calcareous marls (Fig. 6).

The $\mathrm{d}_{18} \mathrm{O}$ carb is generally negative and ranges between 0.5 and $\_2 \&$ in the laminated marls, whereas it displays several positive peaks up to 6 and $8 \&$ in the massive marls, with an overall upward increasing trend. These peaks may record 'pulses' of higher salinity/evaporation that are more intense near the evaporitic unit. The

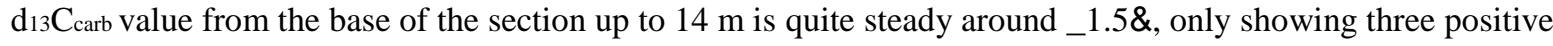


peaks, up to 0,2 and $1 \&$ at the base of the section (ca. $1 \mathrm{~m}$ ), at the upper part of the massive marls (at $8.5 \mathrm{~m}$ ) and at the top of the calcareous marls $(13 \mathrm{~m})$, respectively. In the interval from $15 \mathrm{~m}$ until the top of the pre-evaporitic sequence, the $\mathrm{d}_{13} \mathrm{C}_{\text {carb }}$ values are highly variable (ranging from _ 5 to _ $0.5 \&$ ). The $\mathrm{d}_{18} \mathrm{O}_{\text {multiloba }}$ and $\mathrm{d}_{13} \mathrm{C}_{\text {multiloba remain approximately }}$ constant up $7 \mathrm{~m}$, with average values around 3-4\&and_2.5\&, respectively. From 9.6 up to $19.5 \mathrm{~m}$, the d ${ }_{18} \mathrm{O}$ universa and $\mathrm{d}_{13} \mathrm{C}$ universa exhibit high-frequency and low-amplitude fluctuations ranging from_ 1 to $1 \&$ and $\_0.5$ to $1 \&$, respectively. These are similar to the $\mathrm{d}_{18} \mathrm{O}_{\text {G.obliquus }}$ and $\mathrm{d}_{13} \mathrm{C}_{\mathrm{G} . o b l i q u u s}$ values measured at the basal Trubi Formation; the latter, however, fluctuate more widely, ranging from _2 to $1 \&$ and from 0.5 and $1.4 \&$, respectively. In the upper part of the PLG (cycle $\mathrm{H}$, one metre in the eastern section), the $\mathrm{d}_{18} \mathrm{O}_{\text {carb values range between } 5} 5$ and $8 \&$, whereas $\mathrm{d}_{13} \mathrm{C}_{\text {carb }}$ values mostly fluctuate around_4\& (Fig. 6). The most prominent change, linked to environmental phenomena, seems to be the positive $\mathrm{d}_{18} \mathrm{O}$ shift (ca. 8\&) recorded around the gypsarenite bed, revealing high salinity that is consistent with evaporite deposition (cycles $A-G$ ); therefore, the gypsarenite of cycle $\mathrm{H}$ is probably related to the penecontemporaneous reworking of primary facies belonging to the PLG unit. The $\mathrm{d}_{18} \mathrm{O}$ carb values of ca. _ $3 \&$ are considered indicative of brackish conditions (Pierre \& Rouchy, 1990). Sharp d13C carb negative and positive shifts characterize rapid changes in the hydraulic budget and in the ventilation of the basin, from lacustrine to saline conditions (Shackleton et al., 1995).

The M/P boundary is marked by an excursion towards higher $\mathrm{d}$ values $\left(\mathrm{d}_{18} \mathrm{O}_{\mathrm{G} . \text {.obliquus }}=\_0.75 \&, \mathrm{~d}_{13} \mathrm{C}_{\mathrm{G}}\right.$.

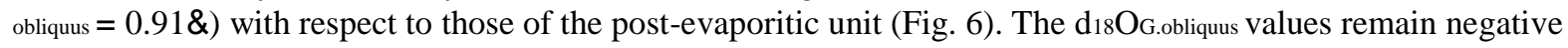
in the black shale just below the Trubi, although they still fall within the range of the Pliocene values. This development could reflect the rapid transition to marine conditions at the onset of the Pliocene. Upward from the

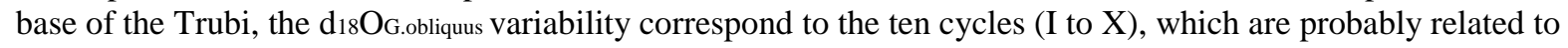
the precessional oscillations (Shackleton et al., 1995; di Stefano \& Sturiale, 2010). The d18OG.obliquus values range between 2 and $1.5 \&$, with lighter values corresponding to laminated marls and heavier ones corresponding to the limestones. The early Pliocene sediments' $d_{13} C_{G}$.obliquus values $\left(0.32<d_{13} C \&<1.39\right)$ present the same frequency

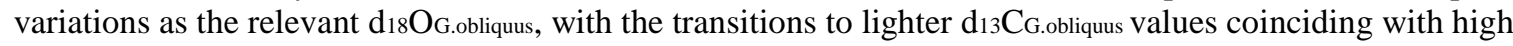
shifts to heavier dis OG.obliquus values (Fig. 6).

\section{Strontium isotopes}

The results of the strontium isotope analyses in the Kalamaki section gypsum unit are presented in Fig. 3. Selenite samples yield $87 \mathrm{Sr} / 86 \mathrm{Sr}$ values of 0.708993 for $(2 \mathrm{r}=0.0014)$ and $0.709007(2 \mathrm{r}=0.0015)$. These values correspond to PLG deposits from stage 1 of the salinity crisis (Roveri et al., 2014a,b). It is worth to notice here that the ${ }_{87} \mathrm{Sr} / 86 \mathrm{Sr}$ values of the worldwide Triassic marine evaporites are lower, ranging between 0.7076 and 0.7082 (Ort_1 et al., 2014).

\section{DISCUSSION}

\section{Chronostratigraphic framework}

The observed distributions of planktonic foraminifer and calcareous nannofossil species were used to recognize astronomically tuned bioevents that are already defined in lower Messinian Mediterranean sections (Fig. 14; Krijgsman et al., 1999a,b; Hilgen \& Krijgsman, 1999; Sierro et al., 2001; Blanc-Valleron et al., 2002; Manzi et al., 2011, 2013). The first peak of T. multiloba is recognized one metre from the base of the western Kalamaki subsection and can be correlated with its first abundant occurrence dated at 6.415 Ma in the Perales section (Sierro et al., 2001). The first abundant occurrence of dextral N. acostaensis, identified also in the Perales section and dated at $6.339 \mathrm{Ma}$, is recorded at $2.7 \mathrm{~m}$. This biostratigraphic event is considered more reliable than the $\mathrm{N}$. acostaensis coiling change as no sinistral specimens were observed below this level. The presence of G. scitula at $3.7 \mathrm{~m}$ can be correlated with its first influx and dated between 6.291 and 6.287 Ma. The interval between 8.8 and $9.2 \mathrm{~m}$, dominated by sinistral N. acostaensis, is correlated with the relevant interval found in the Metochia section (Gavdos Island; Drinia et al., 2007) and in the Perales composite section (Sierro et al., 2001; Manzi et al., 2013), and it is dated between 6.140 and 6.108 Ma. The influx of T. multiloba at $9 \mathrm{~m}$ can be correlated with a relevant influx of this species at Perales section, which falls in the upper part of cycle UA28, dated at 6.121 Ma. The influx of G. scitula at 9.3 m correlates well with the second known influx of this species, dated between 6.105 and 6.099 Ma (Sierro et al., 2001). The dominance of sinistral N. acostaensis identified at $10.4 \mathrm{~m}$ can be correlated with the second influx of sinistral N. acostaensis dated between 6.078 and $6.08 \mathrm{Ma}$, approximately at the same level of the influx of T. multiloba at $10.5 \mathrm{~m}$, which could correspond to the last prominent influx of the species in the Perales section. The oligotypic assemblage recorded below the slumped interval and the high abundance of planktonic foraminifera at $14.3 \mathrm{~m}$ were also observed in the Sorbas Basin and in the Northern Apennines (Sierro et al., 2003; Gennari et al., 2013) preceding the last eccentricity maximum centred at ca. 6.01 Ma, before the onset of the MSC. Based on this biostratigraphic framework, the normal polarity at the lower part of the Kalamaki pre-evaporitic sequence (up to $0.68 \mathrm{~m}$ ) is correlated with subchron C3An.2n (6.733-6.436 Ma after Lourens et al., 2004), 
below the first abundant occurrence of T. multiloba. The reverse magnetic signal at $6.53 \mathrm{~m}$ falls within subchron C3An.1r. This interval is confirmed by the position of the N. acostaensis dextral-coiling specimens' abundant occurrence and the G. scitula first influx. The normal polarities between 8.58 and $12.03 \mathrm{~m}$ correlate with subchron C3An.1n (6.252-6.033 Ma) and the reversal polarities at 14.02-20.15 m fall within the lower part of subchron C3r. As for the calcareous nannofossil, the typical specimens of D. quinqueramus, usually recorded in other pre-evaporitic deposits (e.g. Gavdos Island; Triantaphyllou et al., 1999), are not found in the Kalamaki sequence, probably due to the establishment of a semi-closed, neritic, littoral environment (Wade \& Bown, 2006). However, the presence of N. amplificus supports the biostratigraphic assignment of the Kalamaki pre-evaporitic unit within the NN11 biozone, dated between 6.82 and 5.98 Ma (Raffi et al., 2006; Backman et al., 2012).

Reworked planktonic foraminifera and nannofossil specimens characterize the upper part of the PLG succession and the Lago Mare deposits in the Kalamaki section. Gephyrocapsa spp. specimens, although suggesting an age within the early Pliocene (sub-bottom of Gephyrocapsa spp. at 4.33 Ma; Lourens et al., 2004), were also observed in the late-Messinian pre-evaporitic diatomites of Gavdos (Triantaphyllou et al., 1999). Thus, their presence in the Kalamaki sequence contributes to the limited knowledge on the precise stratigraphic and geographic distribution of these early representatives of the genus in the SE Mediterranean region. Just before the Trubi Formation (Fig. 16), the planktonic foraminifera assemblages in both Kalamaki and Ag. Sostis sections are assigned to the Transitional Unit identified in the ODP sections by Iaccarino et al. (1999). In sample KAL 134, the rare presence of calcareous nannofossil Ceratolithus acutus, together with specimens of Reticulofenestra zancleana, implies an age within the base of the NN12 biozone, in the early Zanclean (5.36 Ma; di Stefano \& Sturiale, 2010; Backman et al., 2012). The M/P boundary (5.33 Ma) is defined by the distribution of dextral and sinistral forms of N. acostaensis and the Sphaeroidinellopsis Acme Base, further supported by the increasing of the oxygen and carbon isotope values, and it is placed at the base of the Trubi Formation. The recognized bioevents and the polarity reversal identified in the lower part of Trubi Formation of Kalamaki section are correlated with the upper part of subchron C3r and the normal polarity at the $\mathrm{C} 3 \mathrm{r} / \mathrm{C} 3 \mathrm{n}$ boundary is placed in the 9.6- to 10.4-m interval mid-point (event III; Fig. 16) dated at 5.235 Ma (Lourens et al., 2004), below the Sphaeroidinellopsis Acme End (5.21 Ma). The sinistral shifts of $\mathrm{N}$. acostaensis at 7.8 and $8.52 \mathrm{~m}$ are ascribed to the first and second N. acostaensis sinistral shifts that are reported from several Mediterranean Lower Pliocene sections (di Stefano et al., 1996; Lourens et al., 1996; Iaccarino et al., 1999; Pierre et al., 2006; Gennari, 2007; Drinia et al., 2008), dated at 5.330 and 5.281 Ma (Lourens et al., 2004) and correlated with the base of cycle 2-top cycle 1 and the base of cycle 2-top cycle 3, respectively. The base of the Sphaeroidinellopsis Acme Zone, recorded at $8.3 \mathrm{~m}$, and its top, at $11.3 \mathrm{~m}$, correspond to the cycle 2 and the base of cycle 6 , respectively. The first common occurrence of Globorotalia margaritae (FCO) is recorded in KAL 171 and marks cycle 10, dated at 5.08 Ma (Lourens et al., 2004). Consequently, the studied Trubi Formation sediments belong to the MPL1 biozone - lower part of the MPL2 biozone; its base may be correlated with the base of the Zanclean, as defined in the Eraclea Minoa GSSP at 5.33 Ma (van Couvering et al., 2000). The presences of Sphenolithus spp. (abundance >5\%), Reticulofenestra pseudoumbilicus (abundance 1-2\%, possibly representing the R. pseudoumbilicus Pliocene Paracme Zone; di Stefano \& Sturiale, 2010), rare Reticulofenestra zancleana, and several discoasterid species (D. brouweri, D. pentaradiatus, D. surculus, D. intercalaris, D. variabilis), in conjunction with the common occurrence of Amaurolithus spp., document the biostratigraphic correlation with the nannofossil biozone NN12 (Martini, 1971), or MNN12a-b (Rio et al., 1990). Therefore, the Trubi sediments of Kalamaki section (Fig. 16) have an early Zanclean age, ranging between 5.36 and 5.0 Ma.

\section{Kalamaki palaeoenvironmental reconstruction}

Pre-evaporitic sequence

The fish assemblage identified in the pre-evaporitic Messinian of Kalamaki section (Fig. 3) is indicative of a coastal marine area, with easy access to the open ocean, not exceeding $300 \mathrm{~m}$ in its deeper parts. The great diversity of the fauna, along with the fact that it incorporates deep-water pelagic species, such as Maurolicus muelleri, Gadiculus argenteus and Physiculus aff. huloti, as well as shallow-water inhabitants, such as gobiids, suggests that fossils from different adjacent underwater domains were combined during deposition. This phenomenon is commonly observed in the otolith faunas and results from the small-distance transportation of the otoliths during deposition, which is attributed to the high bathymetric gradient (Agiadi et al., 2013). Thus, the Kalamaki area palaeogeographic scheme proposed here is further supported by this observation. Several palaeoenvironmental changes can be recognized by the variations of the faunal and isotopic markers resulted to a stepwise progression towards the evaporitic conditions. Interval 6.456.121 Ma (0-9 m). In this interval (KAL 10-50; Fig. 3), the nannofossil assemblage of H. carteri, C. leptoporus, U. jafari, R. haqii and R. minutula is mostly represented by whole coccospheres, indicating high productivity and freshwater input to the surface waters (e.g. Triantaphyllou et al., 2009a,b). In addition, the impressive monospecific assemblages of Sphenolithus abies in the upper part of this interval (samples KAL 45- 55) suggest marine mesotrophic environments (Wade \& Bown, 2006) and were observed in others coeval Mediterranean sites (Cyprus, Kouwenhoven et al., 2006; Piedmont, Lozar et al., 2010 and north-eastern Apennine, Manzi et al., 2007). In this basal part of the preevaporitic sequence, the bulk sediment $d_{18} \mathrm{O}$ values range between 0 and $2.1 \&$, reflecting marine conditions with slightly increased salinity and/or temperature (Fig. 6). The positive trend of $\mathrm{d}_{13} \mathrm{C}_{\text {carb }}$ reveals high productivity related to cold 
waters. The oligotypic planktonic foraminifera record is characterized by levels with 60-100\% dominance of T. multiloba (KAL 7-KAL 10). This species is related to progressive isolation of the Mediterranean, and it is thought to be tolerant to increased salinity (Sierro et al., 2001). Its occurrence together with T. quinqueloba and G. glutinata in this part of the section is related to cold and nutrient rich surface waters (B_e \& Tolderlund, 1971; Sierro et al., 2003). This is confirmed by its isotopic signature, showing d ${ }_{18}$ Omultiloba values greater than $3 \&$, which could record the upwelling of deep-intermediate cold water, possibly characterized by slightly raised salinity. According to the position of the Kalamaki section within the Mediterranean, this water mass could represent the deepintermediate water mass formed in the eastern Mediterranean and flowing to the west and to the north into the proto-Adriatic (Kouwenhoven et al., 2006). The peaks of T. multiloba in the Mediterranean have been correlated to the insolation minima (Sierro et al., 2003), and they coincide with the late Miocene glacial cycles (Gennari et al., 2013). The low planktonic foraminifera diversity 2-4 $\mathrm{m}$ from the base is associated with the $\mathrm{d}_{18}$ Obulk negative excursions, nannofossil assemblages indicative of high productivity and freshwater input, and suggests a temporary restriction of the Mediterranean-Atlantic connection (e.g. during a sea-level fall, or excess precipitation) at this time, leading to a reduction of the sea-surface salinity. Within this barren interval, at $3.7 \mathrm{~m}$, the return to normal marine conditions is inferred by the oxygen isotope positive values and the influx of the deep-dwelling (B_e \& Tolderlund, 1971) species G. scitula. Maximum d ${ }_{18}$ Obulk values are observed between 7 and $9 \mathrm{~m}$ and correspond to hypersalinity episodes. The increased $\mathrm{d}_{18} \mathrm{O}$ bulk values coincide wi th higher abundance of the small-sized microfaunas (G. glutinata and T. quinqueloba) which are related to cold-eutrophic surface waters and/or high salinity.

Relevant horizons characterized as 'aplanktonic zones' or 'nearly aplanktonic zones' have been recorded in Upper Abad Section and in Red Sea related to high salinity and cold surface waters. These conditions were unfavourable for planktonic foraminifera to survive (Sierro et al., 1999; Hemleben et al., 1996). However, climatic variability towards a cooling phase is recorded around 6.121 Ma by Van der Laan et al. (2005) and Gennari (2003). At the upper part of this interval around $9 \mathrm{~m}$, the $\mathrm{d}_{18} \mathrm{O}$ carb values average around $0 \&$ indicating periods when normal marine conditions prevailed. Interval 6.122-5.97 Ma (9-22 m). The nannoflora assemblages in the upper part of the basal Kalamaki sequence are indicative of a marine mesotrophic environment. Towards the top and before the deposition of the gypsum, the $\mathrm{d}_{18} \mathrm{O}$ carb varies between _4 and 8\&, suggesting rapid salinity fluctuations between highly evaporated and diluted conditions (Bellanca et al., 2001). Additionally, there is a simultaneous decrease in

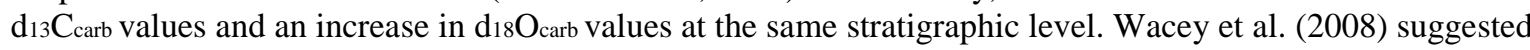
that such a phenomenon could be the result of isotopically light carbon influence from bacterial sulphate reduction, due to increased stagnation at the beginning of sulphate deposition. Similar trends in both carbon and oxygen isotopes were described in the Legnagnone section (Northern Apennines, Italy) by Gennari et al. (2013). As O. universa proliferates in mixed-layer surface waters during surface-water stratification, the $\mathrm{d}_{18}$ Oo.universa reflects slight variations of temperature, freshwater input, or trophic content (Sierro et al., 2003). There is a $4 \&$ difference between the $d_{13} \mathrm{C}$ values in the upper and lower part of the basal Kalamaki interval. This probably reflects the contrast between nutrient-depleted waters of the stratified summer mixed layer, recorded in the upper part of the basal sequence, and the increased nutrient availability of the basal interval ( $\mathrm{d}_{13} \mathrm{C}_{\mathrm{T}}$.multiloba). A cooling phase punctuated by hypersaline conditions (evidenced by a remarkable similarity between the $d_{18} \mathrm{O}_{\text {carb }}$ and the $\mathrm{d}_{18}$ Oo.universa) is centred at $12 \mathrm{~m}$, and may be delimited by the levels of increased freshwater input and the warmer phases evidenced by the fish fauna and planktonic foraminifera assemblages. Indeed, the fish fauna is dominated by warm-water species, notably Diaphus taaningi and Physiculus aff. huloti in the intervals below and over this cooling phase, whereas these taxa are completely absent in the cooling phase, which is characterized by the presence of Maurolicus muelleri mostly preferring temperate conditions. The onset of MSC is accompanied by the disappearance of plankton assemblages, heavier oxygen isotopic values and a sharp negative carbon isotope shift. Post-evaporitic sequence The establishment of rather eutrophic conditions may be hypothesized, based on the presence of small placoliths, along with the siliciclastic nature of the sediments at the uppermost part of the Kalamaki Lago Mare unit, just before the onset of Trubi Formation (e.g. Young, 1994). The samples from approximately one metre below the Agios Sostis Trubi Formation (Fig. 4) contain (AS 20-23) moderately preserved nannofossil assemblages and more reworked material with respect to the Kalamaki samples, indicating greater land proximity.

In the interval 5.6-5.33 Ma (1.4-7.5 m), from the top of the gypsum unit to the beginning of the Trubi Formation, the bulk sediment $\mathrm{d}_{18} \mathrm{O}$ values vary widely from $8 \&$ in the gypsum to _ $6 \&$ in the upper part of the sequence.

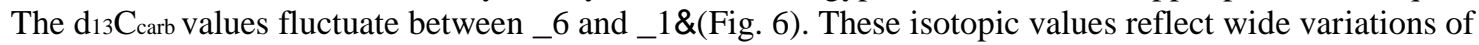
the palaeoenvironmental conditions from hypersaline conditions to fresh and brackish water.

The total nannofossil content in the interval just above the Miocene/Pliocene (M/P) boundary in the Kalamaki section implies warm surface-water conditions in a pelagic environment. In particular, the presence of discoasterids, Rhabdosphaera spp., Sphenolithus spp., Scyphosphaera spp., Amaurolithus spp. is indicative of warm subtropical conditions (e.g. Rio \& Sprovieri, 1986). Relatively increased productivity is inferred by the presence of Helicosphaera carteri, a species preferring warm waters and moderately elevated nutrient levels. The faunal assemblages as well as the isotope analyses reveal an open marine, stable and well-ventilated environment, settled at the beginning of the Zanclean, due to the restoration of normal marine conditions. The concurrent $\mathrm{d}_{18} \mathrm{OG}_{\text {G.obliquus }}$ increase and $\mathrm{d}_{13} \mathrm{C}_{\mathrm{G}}$.obliquus decrease are possibly related to sea-surface temperature variations 
and reveal that the glacial cycles (Sprovieri et al., 2006) also influenced the eastern Mediterranean during the early Pliocene.

\section{Zakynthos Neogene palaeogeographic and structural evolution}

Field observations show that the Neogene sediments in the main part of Zakynthos Island, west of the Ionian thrust, were deposited over the pre-Apulian zone formations, whereas those in the south-eastern part, east of the Ionian thrust, were deposited over the Ionian zone. The correlation of the field observations with the available borehole data and the onshore seismic section (Figs 2, 12 and 13) reveals that the Neogene formations over the preApulian zone sediments, east of the Vrahionas anticline (Fig. 2), form a monocline dipping approximately 30_ ESE. Onshore seismic section (Figs 2 and 13) and boreholes stratigraphy (Fig. 12) indicate that the Neogene deposits (gypsum included) increase their thickness towards the dipping monocline. The Neogene sediments exhibit their maximum thickness (800-1350 m) within the largest depocentre zone, extending eastward from the Agios Sostis area. The westernmost gypsum outcrops (Ploumari) consist of transported PLG blocks, whereas the easternmost ones (Panagia) contain gypsum turbidites and gypsum cumulates (Fig. 2). Consequently, the PLG deposits accumulated in a shallow marine basin, which was located in the western part of the Zakynthos (Alikanas) basin (west of the Ploumari outcrops; Fig. 2), and they were almost completely eroded during late Messinian. Indeed, about one km north of the Keri village (Fig. 2), in the Perlakia location, early Pliocene conglomerates, and sandstones lie over the early-middle Miocene marls through an angular unconformity. Thus, the eroded PLG deposits provided the clastic material that was deposited as gypsum turbidites (RLG) along the Messinian basin slope (Panagia outcrops) and in its depocentre. In addition, dismantled PLG blocks slid towards the slope and were incorporated in the RLG deposits. On the contrary, Neogene sediments over the Ionian zone formations in the south-easternmost part of the island are considerably thinner (200-300 m). Gypsum deposits in Kalamaki and Argassi areas correspond to MSC stage 1 PLG unit; to the east (Skopos area, Fig. 2), only some rare and small gypsum outcrops can be observed, mainly reworked gypsum and occasionally gypsum turbidites. These differences suggest that the Zakynthos Neogene basin was not uniform, but subsidence in the monocline area (over pre-Apulian basement) was more rapid as compared with the eastern area (over Ionian basement). The above observations are explained by a simple model of continental foreland-directed migration of the Hellenide (Alpine) thrusting, during the late Neogene and Pliocene. The Ionian thrust foreland basin can be modelled according to the foreland basin systems proposed by de Celles \& Giles (1996), although it is necessary to take into consideration the particular role of the Ionian Triassic evaporites diapiric movements (Fig. 1; Karakitsios, 1995). The Neogene formations over the pre-Apulian zone correspond to the foredeep, the forebulge and flank between them; those overlying Ionian zone rocks correspond to the wedge-top (Fig. 17). The wedge-top is more extensive in this foreland basin due to the extensive diapirism of the Triassic evaporites as compared to a foreland basin without an evaporitic base. At the same time, the diapirism induced tectonic activity, which limited the width of the foredeep zone. The greater subsidence characterizing the foredeep and flank-to-forebulge areas is reflected in the increased thickness of the clastic Neogene formations over the pre-Apulian zone, which partially derived from the eroded pre-Apulian forebulge-backbulge. Simultaneously, the diapiric movement of the Ionian Triassic evaporites, mainly halite and anhydrite (Karakitsios \& Pomoni-Papaioannou, 1998; Pomoni- Papaioannou et al., 2004), prevented substantial subsidence to occur. As a result, the eastern part of the Neogene basin over the Ionian zone basement corresponds to a slowly subsiding wedge-top. This is reflected in the observed thin clastic Neogene sediments derived from the Ionian orogen's erosion.

During the Messinian, the shallow depths in the wedge-top and forebulge-backbulge area of the basin, together with the upper Messinian overall negative hydrological balance (Mertz-Kraus et al., 2009) led to the deposition of the PLG. The subsequent PLG erosion produced clastic gypsum that was deposited through gravity flows in the slope and the depocentre, in analogy with the situation observed in Belice section (Sicily; Roveri et al., 2006; Lugli et al., 2010), although the contact between the RLG and Lago Mare was not observable in Agios Sostis section. In addition, PLG mass flows were accumulated in the distal Zakynthos foreland slope.

Therefore, the Agios Sostis evaporites correspond to a mass flow, which slid from the west to the east, following the dipping of the slope between the forebulge and the foredeep of the Zakynthos (Alikanas) basin.

Consequently, the Agios Sostis evaporitic unit can only be interpreted as derived from the dismantlement and resedimentation of the western PLG deposits. It would not be possible for them to originate from the Triassic diapirs, which are located to the east. Furthermore, during the Messinian, the Triassic diapirs were largely covered by the Neogene sediments (Fig. 17A). By the end of the Messinian, the PLG unit was completely eroded at the forebulge-backbulge zone, probably due to subaerial exposure. The MES (Fig. 17) is located directly above the pre-evaporitic sequence west of the Ploumari gypsum outcrops (Fig. 2), and it passes over the remaining PLG in the proximal slope (Ploumari gypsum outcrops). In the distal slope and the foreland depocentre, the MES becomes a correlative conformity. The wedge-top zone was characterized by shallower depths, mainly due to the diapiric uplift of the Ionian Triassic evaporites (Karakitsios, 1995). Indeed, the sea depth in the Kalamaki area, prior to the PLG deposition, is estimated up to $300 \mathrm{~m}$, based on the fish assemblages. Consequently, the Kalamaki area, placed over the external Ionian Triassic diapir (Agia Dynati diapir; Figs 2 and 17), received PLG deposits. Eroded gypsum material from the wedge-top PLG also supplied clastic gypsum to the foredeep RLG unit, which was located to its west (Fig. 17A). Possibly, the last cycle of the PLG deposits in Kalamaki section (clastic gypsum in cycle H) derived 
from the remained eastern wedge-top primary gypsum deposits, which were exposed and eroded at that time. In the Argassi area, PLG was also deposited over the Agios Ioannis diapir; the upper PLG part was subsequently eroded. Quaternary erosion obscures the continuation of the deposited sediments of this area. Possibly the Argassi and Kalamaki sections during PLG deposition belonged to the same evaporitic basin that was separated by an early activation of the Agios Ioannis diapir (Fig. 17A). The proposed palaeogeographic scheme for the last period of the Trubi Formation's deposition is presented in Fig. 17B. The LagoMare unit lies unconformably over the MES in the wedge-top (Kalamaki area), whereas in the distal slope and in the depocentre it was deposited with a correlative conformity. The Trubi Formation succeeds the Lago Mare unit, in stratigraphic continuity. The onset of the Trubi Formation at 5.33 Ma, corresponding to the Pliocene flooding of the Mediterranean basin, is recorded well on Zakynthos Island. The present results indicate that the Messinian gypsum units of Zakynthos Island were deposited in a Mediterranean peripheral/marginal basins context (sensu Roveri et al., 2014a), formed during the late Messinian in the pre- Apulian foreland basin, before the early Pliocene main deformation phase responsible for the tectonic emplacement of the Ionian zone over the pre-Apulian zone. The distribution of the Messinian evaporites on Zakynthos Island clearly agrees with the CIESM (2008) stratigraphic scheme, which was described in many western (Apennines; Manzi et al., 2005; Sicily, Roveri et al., 2008a; Manzi et al., 2011; Spain, Omodeo-Sale et al., 2012; Matano et al., 2014) and eastern (Cypsus, Manzi et al., 2015; Israel, Lugli et al., 2013) Mediterranean areas. It is characterized by primary bottom-grown selenite (PLG) deposited in marginal shallow-water settings and by their subsequent deep erosion and resedimentation in the deepest parts of the basin as submarine mass waste and turbidites (RLG). The main particularity of the Zakynthos foreland basin is that the Triassic evaporitic diapirs controlled its configuration and subsidence.

\section{CONCLUSIONS}

Our integrated study provides a detailed reconstruction of the geological, stratigraphic, tectonic, palaeogeographic and palaeoenvironmental evolution of the Zakynthos Island during the Messinian. The development and distribution of the depositional environments before the major Ionian thrust activa tion was mainly influenced by the Triassic evaporites diapiric movements in the foreland basin and has profound effects on the distribution of the Messinian evaporites. - Shallow-water $(<200 \mathrm{~m})$ bottom-grown selenite evaporites belonging to the PLG were accumulated in the wedge-top basin on top of Ionian alpine basement and in the backbulge-forebulge zones developed on top of the pre-Apulian units.

- During the MSC stage 2, the PLG unit was deeply eroded at the shallow basins and was resedimented as clastic evaporites in the deeper foredeep, which was developed at the contact of the two tectonic units; minor gypsum cumulate primary facies were also deposited.

- In the pre-Apulian area, the clastic evaporites change laterally from mass-wasting Messinian gypsum, in the west, to gypsum turbidites indicating a deeper environment, in the east.

- In the wedge-top, the MES is overlapped by the Lago Mare unit, over which the Trubi Formation lies in stratigraphic continuity. Planktonic foraminifera and calcareous nannoplankton biostratigraphy, magnetostratigraphy and correlation with astronomically tuned Mediterranean sections provide the chronostratigraphic framework for the studied sequences.

- The pre-evaporitic sequence in Kalamaki section is dated between 6.415 and 6.01 Ma. Nine planktonic foraminiferal bioevents are distinguished.

- In Kalamaki section, PLG was deposited during the first MSC stage, between 5.971 and 5.60 Ma.

- The resedimented PLG deposits observed in Agios Sostis area correspond to the second MSC stage (5.6$5.55 \mathrm{Ma})$.

- The M/P boundary is placed at the base of the Trubi Formation, dated at 5.33 Ma. The Kalamaki section Trubi Formation, corresponds to the interval between 5.33 and 5.08 Ma, in which five planktonic foraminiferal bioevents are distinguished. The presented palaeoenvironmental reconstruction of the pre-evaporitic Messinian in Kalamaki can be summarized as follows:

- 6.45-6.2 Ma (0-7 m) - marine conditions prevailed, with slight salinity and temperature variations. The positive $\mathrm{d}_{13} \mathrm{C}_{\mathrm{carb}}$ trend and the oligotypic planktonic foraminiferal assemblage, dominated by $\mathrm{T}$. multiloba, indicate high-productivity cold waters

-6.2-6.14 Ma (7-9 m) - high $\mathrm{d}_{18} \mathrm{O}_{\text {carb }}$ corresponding to hypersalinity episodes alternate with normal salinity conditions with decreased food availability and low temperature

- 6.122-5.97 Ma (9-22 m) - marine mesotrophic conditions are well established; the isotopic record suggests nutrient-depleted waters of the stratified summer mixed layer

- around $6.05 \mathrm{Ma}(12 \mathrm{~m})$ - a cooling phase punctuated by hypersalinity episodes is indicated by both the planktonic foraminifera and the fish assemblage

- In the upper part of the pre-evaporitic sequence, the observed synchronous decrease in the carbon isotopic ratio, and increase in the oxygen isotopic ratio may be caused by isotopically light carbon input from bacterial sulphate reduction, due to increasing stagnation at the beginning of sulphate deposition.

After the MSC, eutrophic conditions are indicated at the uppermost part of the Lago Mare facies unit, just before the onset of Trubi limestone Formation. 


\section{ACKNOWLEDGEMENTS}

This research has been cofinanced by the European Union (European Social Fund - ESF) and Greek National Funds through the Operational Program 'Education and Lifelong Learning' of the National Strategic Reference Framework (NSRF) - Research Funding Program: THALIS- UOA-'Messinian Salinity Crisis: the greatest Mediterranean environmental perturbation and its repercussions to the biota'. The authors would like to thank Dr. Rachel Flecker and the anonymous reviewer for their valuable and constructive comments on the manuscript.

\section{SUPPORTING INFORMATION}

Additional Supporting Information may be found in the online version of this article: Appendix S1. Oxygen and carbon stable isotope measurements in the Kalamaki section. Table S1. Nannofossil abundances in Kalamaki section sediments. Table S2. Planktonic foraminifera abundances in Kalamaki section sediments.

\section{REFERENCES}

AGIADI, K. (2013) Investigation of the Plio-Pleistocene eastern Mediterranean Ichthyofauna and paleoenvironmental representations on Rhodes and Crete Islands, $\mathrm{PhD}$ Thesis, University of Athens.

Agiadi, K., Triantaphyllou, M., Girone, A., Karakitsios, V. \&DermitZaKis,M. (2010) Paleobathymetric interpretation of the fish otoliths from the lower - middle quaternary deposits of Kephallonia and Zakynthos Islands (Ionian Sea, Western Greece). Riv. Ital. Paleontol. Stratigr., 116(1), 63-78. Agiadi, K., Triantaphyllou, M., Girone, A. \& Karakitsios, V. (2011) The early quaternary palaeobiogeography of the Eastern Ionian deep-sea Teleost fauna: a novel palaeocirculation approach. Palaeogeogr. Palaeocl., 306(3-4), 228-242.

Agiadi, K., Koskeridou, E., Triantaphyllou, M., Girone, A. \& Karakitsios, V. (2013) Fish otoliths from the Pliocene Heraklion Basin (Crete Island, Eastern Mediterranean). Geobios, 46, 461-472.

van Assen, E., Kuiper, K.F., Barhoun, N., Krijgsman, W. \& Sierro, F.J. (2006) Messinian astrochronology of the Melilla Basin: stepwise restriction of the Mediterranean-Atlantic connection through Morocco. Palaeogeogr. Palaeoclimatol.

Palaeoecol., 238, 15-31.

Aubry, M.-P. (1984, 1988, 1989, 1990, 1999) Handbook of Cenozoic Calcareous Nannoplankton. Vol. 1-5, Micropress, American Museum of Natural History, New York.

Backman, J., Raffi, I., Rio, D., Fornaciari, E. \& P€alike, H. (2012) Biozonation and biochronology of Miocene through Pleistocene calcareous nannofossils from low and middle latitudes. Newsl. Stratigr., 45(3), 221-244.

Baumann, K.-H., Andruleit, H., B€ockel, B., Geisen, M. \& KINKEL, H. (2005) The significance of extant coccolithophores as indicators of ocean water masses, surface water temperature, and paleoproductivity: a review. Pal€aontol. Z., 79, 93-112.

B_E, A.W.H. \& Tolderlund, D.S. (1971) Distribution and ecology of living planktonic foraminifera in surface waters of the Atlantic and Indian Oceans. In: The Micropaleontology of Oceans (Ed. by B.M. Funnel, W.R. Riedel), pp. 105-149. Cambridge University Press, Cambridge.

Bellanca, A., Caruso, A., Ferruzza, G., Neri, R., Rouchy, J.M., Sprovieri, M. \& Blanc-Valleron, M.M. (2001) Transition from marine to hypersaline conditions in the Messinian Tripoli Formation from the marginal areas of the central Sicilian Basin. Sed. Geol., 140(1-2), 87-105.

BIRCK, J. (1986) Precision K-Rb-Sr isotope analysis: application to $\mathrm{Rb}-\mathrm{Sr}$ chronology. Chem. Geol., 56, 73-83.

Blanc-Valleron, M.-M., Pierre, C., Caulet, J.P., Caruso, A., Rouchy, J.-M., Cespuglio, G., Sprovieri, R., Pestrea, S. \& di Stefano, E. (2002) Sedimentary, stable isotope and micropaleontological records of paleoceanographic change in the Messinian Tripoli Formation (Sicily, Italy). Palaeogeogr. 
Palaeoclimatol. Palaeoeocol., 185, 255-286.

Bown, P.R. \& Young, J.R. (1998) Techniques. In: Calcareous

Nannofossil Biostratigraphy (Ed. by P.R. Bown), pp. 16-28.

Kulwer Academic Publications, Dordrecht.

BP Co. Ltd. (1971) The Geological results of petroleum exploration

in western Greece. Institute for Geology and Subsurface

Research (now I.G.M.E.). Special Report, 10, Athens.

Carnevale, G., Landini, W. \& SARTi, G. (2006) Mare versus

Lago-mare: marine fishes and the Mediterranean environment at the end of the Messinian Salinity Crisis. J. Geol. Soc.

Lond., 163, 75-80.

Carnevale, G., Longinelli, A., Caputo, D., Barbieri, M. \&

LANDINI, W. (2008) Did the Mediterranean marine reflooding

precede the Mio-Pliocene boundary? Paleontological and geochemical

evidence from upper Messinian sequences of Tuscany,

Italy. Palaeogeogr. Palaeoclimatol. Palaeoecol., 257(1-2),

81-105.

de Celles, P.G. \& Giles, K.A. (1996) Foreland basin systems.

Basin Res., 8(2), 105-123.

Chadima, M. \& Hrouda, F. (2006) Remas of t 3.0 a user

friendly paleomagnetic data browser and analyzer. Trav.

G_eophys., 27, 20-21.

CIESM (2008) The Messinian salinity crisis from mega-deposits

to microbiology. A consensus report. In: 33_eme CIESM

Workshop Monographs (Ed. by F. Briand), $91-96$, Monaco.

Cohen, D.M., Inada, T., Iwamoto, T. \& Scialabba, N. (1990)

FAO Species Catalogue. Vol.10. Gadiform fishes of the world

(Order Gadiformes). An annotated and illustrated catalogue

of cods, hakes, grenadiers and other gadiform fishes known to

date. FAO Fish. Synop., 125(1), pp. 442, FAO, Rome.

van Couvering, J.A., Castradori, D., Cita, M.B., Hilgen, F.J.

\& Rio, D. (2000) The base of the Zanclean stage and of the

Pliocene series. Episodes, 23, 179-187.

Cros, L. (2001) Planktonic coccolithophores of the NW

Mediterranean. PhD Thesis, Departament d'Ecologia,

Universitat de Barcelona, Barcelona.

Dela Pierre, F., Clari, P., Bernardi, E., Natalicchio, M.,

Costa, E., Cavagna, S., Lozara, F., Lugli, S., Manzi,

V., Roveri, M. \& Violanti, D. (2012) Messinian carbonate-

rich beds of the Tertiary Piedmont Basin (NW Italy):

microbially-mediated products straddling the onset of the

salinity crisis. Palaeogeogr. Palaeoclimatol. Palaeoecol., 344-Drinia, H., Antonarakou, A. \& Kontakiotis, G. (2008)

On the occurence of early Pliocene marine deposits in the

Ierapetra basin, Eastern Crete, Greece. Bull. Geosci., 83(1),

63-78.

Duermeijer, C.E., Krijgsman, W., Langereis, C.G., Meulenkamp,

J.E., Triantaphyllou, M.V. \& Zachariasse, W.J.

(1999) A late Pleistocene clockwise rotation phase of Zakynthos

(Greece) and implications for the evolution of the western

Aegean arc. Earth Planet. Sci. Lett., 173(3), 315-331.

Fabricius, F.H., HeImann, K.O. \& BRaune, K. (1998) Comparison

of site 274 with circum-Ionian land sections: implications

for the Messinian "salinity crisis" on the basis of a dynamic

model. Initial Rep. DSDP, 42, 927-942.

Flecker, R., de Villiers, S. \& Ellam, R.M. (2002) Modelling

the effect of evaporation on the salinity-87 $\mathrm{Sr} / 86 \mathrm{Sr}$ relationship

in modern and ancient marginal-marine systems: the

Mediterranean Messinian Salinity Crisis. Earth Planet. Sci.

Lett., 203(1), 221-233.

Flores, J.A., Sierro, F.J., FilipPelli, G.M., B_arcena, M.A.,

P_EREZFolgado, M., V_AZQuez, A. \& Utrilla, R. (2005) Surface

water dynamics and phytoplankton communities during

deposition of cyclic late Messinian sapropel sequences in the

western Mediterranean. Mar. Micropaleontol., 56, 50-79.

Fortuin, A.R. \& Krijgsman, W. (2003) The Messinian of the

Nijar Basin (SE Spain): sedimentation, depositional environments

and paleogeographic evolution. Sed. Geol., 160(1-3),

213-242. 
Froese, R. \& Pauly, D. (2014) FishBase. World Wide Web electronic publication, www.fishbase.org, version (08/2014).

Garcia-Castellanos, D., Estrada, F., Jim_enez-Munt, I., Gorini, C., Fern_andeZ, M., Verg_es, J. \& de Vicente, R.

(2009) Catastrophic flood of the Mediterranean after the Messinian salinity crisis. Nature, 462, 778-781.

GENNARI, R. (2003) Stratigrafia fisica ed evoluzione strutturale al passaggio Mio-Pliocene nella Val Sporzana (Appennino settentrionale). Unpublished Thesis, University of Parma.

GenNari, R. (2007) Cause e modalit_a della formazione messiniana

"LagoMare" e passaggio al Pliocene. PhD Thesis,

University of Parma, Parma.

Gennari, R., Iaccarino, S.M., Di Stefano, A., Sturiale, G.,

Cipollari, P., Manzi, V., Roveri, M. \& Cosentino, D.

(2008) The Messinian - Zanclean boundary in the Northern

Apennine. Stratigraphy, 5(3-4), 307-322.

Gennari, R., Manzi, V., Angeletti, L., Bertini, A., Biffi, U.,

Ceregato, A., Faranda, C., Gliozzi, E., Lugli, S., Menichetti,

E., Rosso, A., Roveri, M. \& Taviani, M. (2013) A

shallow water record of the onset of the Messinian salinity crisis

in the Adriatic foredeep (Legnagnone section, Northern

Apennines). Palaeogeogr. Palaeoclimatol. Palaeoecol., 386,

145-164.

Gignoux, M. (1936) G_eologie Stratigraphique. 2nd_edn, pp. 709,

Masson, Paris.

Girone, A., Nolf, D. \& Cavallo, O. (2010) Fish otoliths from the preevaporitic (Early Messinian) sediments of northern

Italy: their stratigraphic and palaeobiogeographic significance.

Facies, 56, 399-432.

Hemleben, C.H., Spindler, M. \& Anderson, O.R. (1989) Modern

Planktonic Foraminifera. Springer, New York, pp. 1-363.

Hemleben, C., Meischner, D., Zahn, R., Labin, A.A., Erlenkeuser,

H. \& HiLLER, B. (1996) Three hundred eighty thousand

year long stable isotope and faunal records from the Red

Sea: influence of global sea level change on hydrography.

Paleoceanography, 11, 147-156.

Hilgen, F.L. \& KriJgSman, W. (1999) Cyclostratigraphy and astrochronology of the Tripoli diatomite formation (preevaporite Messinian, Sicily, Italy). Terra Nova, 11, 16-22.

Hilgen, F., Kuiper, K., Krijgsman, W., Snel, E. \& van der LAAN, E. (2007) Astronomical tuning as the basis for high resolution chronostratigraphy: the intricate history of the Messinian Salinity Crisis. Stratigraphy, 4(2/3), 231-238.

Hsu, K.J., Ryan, W.B.F. \& CitA, M.B. (1973) Late Miocene

desiccation of the mediterranean. Nature, 242, 240-244.

Hulley, P.A. (1990) Myctophidae. In: Checklist of the Fishes of

the Eastern Tropical Atlantic (CLOFETA), (Ed. by S.C.

Quero, J.C. Hureau, C. Karrer, A. Post \& L. Saldanha), vol.

1, pp. 398-467, JNICT, SEI and UNESCO, Lisbon and

Paris.

Iaccarino, S.M., Premoli SilVA, I., Biolzi, M., Foresi, L.M.,

Lirer, F., Turco, E. \& Petrizzo, M.R. (2007) Practical Manual of Neogene Planktonic Foraminifera. pp. 1-180. Universit_a di Perugia Press International School on Planktonic Foraminifera, (Neogene Planktonic Foraminifera), Perugia.

Iadanza, A., Sampalmieri, G., Cipolllari, P., Mola, M. \&

Cosentino, D. (2013) The "Brecciated Limestones" of

Maiella, Italy: rheological implications of hydrocarboncharged

fluid migration in the Messinian Mediterranean

Basin. Palaeogeogr. Palaeoclimatol. Palaeoecol., 390, 130-

147.

IGRS-IFP (1966) Etude G_eologique De L'epire (Gr_ece Nord-Occidentale).

306.

KARAKITSIOS, V. (1995) The influence of preexisting structure and halokinesis on organic matter preservation and thrust system evolution in the Ionian basin, northwestern Greece.

AAPG Bull., 79, 960-980.

KARAKITSIOS, V. (2013) Western Greece and Ionian Sea petroleum 
systems. AAPG Bull., 97(9), 1567-1595.

Karakitsios, V. \& Pomoni-Papaionnnou, F. (1998) Sedimentological study of the Triassic solution-collapse breccias of the

Ionian zone (NW Greece). Carbonates Evaporites, 13(2), 207-

218.

KARAKITSIOS, V. \& RigaKIS, N. (2007) Evolution and petroleum potential of western Greece. J. Pet. Geol, 30(3), 197-218.

Kokkalas, S., Kamberis, E., Xypolias, P., Sotiropoulos, S. \& Koukouvelas, I. (2013) Coexistence of thin- and thickskinned tectonics in Zakynthos area (western Greece):

insights from seismic sections and regional seismicity.

Tectonophysics, 597-598, 73-84.

Kontopoulos, N., Zelilidis, A., Piper, D.J.W. \& Mudie, P.J.

(1997) Messinian evaporites in Zakynthos, Greece. Palaeogeogr.

Palaeoclimatol. Palaeoecol., 129 (3-4), 361-367.

Kouwenhoven, T.J. \& van der ZwAan, G.J. (2006) A reconstruction

of late Miocene Mediterranean circulation patterns

using benthic Foraminifera. Palaeogeogr. Palaeoclimatol.

Palaeoecol., 238(1-4), 373-385.

Kouwenhoven, T.J., Seidenkrantz, M.-S. \& van der ZwaAn,

G.J. (1999) Deep-water changes: the near-synchronous disappearance

of a group of benthic Foraminifera from the late

Miocene Mediterranean. Palaeogeogr. Palaeoclimatol.

Palaeoecol., 152, 259-281.

Kouwenhoven, T.J., Hilger, F.J. \& van der ZwaAn, G.J.

(2003) Late Tortonian-early Messinian stepwise disruption

of the Mediterranean-Atlantic connections: constraints from

benthic foraminiferal and geochemical data. Palaeogeogr.

Palaeoclimatol. Palaeoecol., 198(3-4), 303-319.

Kouwenhoven, T.J., Morigi, C., Negri, A., Giunta, S., KriJgsman,

W. \& Rouchy, J.-M. (2006) Paleoenvironmental evo-

345, 78-93.

DeRMITZAKIS, M. (1977) Stratigraphy and sedimentary history

of the Miocene of Zakynthos (Ionian Islands, Greece). Ann.

Geol. Pays Hell., 29, 47-186.

Dimiza, M.D., Triantaphyllou, M.V. \& Dermitzakis, M.D.

(2008) Seasonality and ecology of living coccolithophores in

E. Mediterranean coastal environments (Andros Island, Middle

Aegean Sea). Micropaleontology, 54, 159-175.

Dimiza, M.D., Triantaphyllou, M.V. \& Malinverno, E.

(2014) New evidence for the ecology of Helicosphaera carteri

in polluted coastal environments (Elefsis Bay, Saronikos Gulf,

Greece). Journal of Nannoplankton Research, 34, special issue

Coccolithophores 2014 INA workshop.

Drinia, H., Antonarakou, A., Tsaparas, N. \& Kontakiotis,

G. (2007) Palaeoenvironmental conditions preceding the

MSC: a case study from Gavdos Island. Geobios, 40, 251-265. lution of the eastern Mediterranean during the Messinian:

constraints from integrated microfossil data of the Pissouri

Basin (Cyprus). Mar. Micropaleontol., 60(1), 17-44.

Krijgsman, W., Langereis, C.G., Zachariasse, W.J., Boccaletti,

M., Moratti, G., Gelati, R., Iaccarino, S.,

PAPANI, G. \& VIlLA, G. (1999a) Late Neogene evolution of

the Taza-Guercif Basin (Riffian Corridor, Morocco) and

implications for the Messinian salinity crisis. Mar. Geol., 153

(1-4), 147-160.

Krijgsman, W., Hilgen, F.J., RafFi, I., Sierro, F.J. \& Wilson,

D.S. (1999b) Chronology, causes and progression of the Messinian

salinity crisis. Nature, 400, 652-655.

Krijgsman, W., Blanc-Valleron, M.-M., Flecker, R., Hilgen,

F.J., Kouwenhoven, T.J., Merle, D., Orszeg-Sperber,

F. \& Rouchy, J.-M. (2002) The onset of the Messinian salinity

crisis in the Eastern Mediterranean (Pissouri Basin,

Cyprus). Earth Planet. Sci. Lett., 194(3-4), 299-310.

de Lange, G.J. \& KriJgsman,W. (2010) Messinian Salinity Crisis:

a novel unifying shallow gypsum/ deep dolomite formation

mechanism. Mar. Geol., 275, 273-277.

Laskar, J., Robutel, P., Joutel, F., Gastineau, M., Correia,

A. \& LeVraRD, B. (2004) A long-term numerical solution for 
the insolation quantities of the earth. Astron. Astrophys., 428, 261-285.

Lourens, L.J., Antonarakou, A., Hilgen, F.J., van Hoof, A.A.M., Vergnaud-GrazZini, C. \& Zachariasse, W.J. (1996) Evaluation of the Plio-Pleistocene astronomical timescale. Paleoceanography, 11, 391-413.

Lourens, L., Hilgen, F., Shackleton, N.J., Laskar, J. \& WiLson, J. (2004) The Neogene period. In: A Geologic Time Scale 2004 (Ed. by F.M. Gradstein, J.G. Ogg, A.A. Smith), pp. 409-440. Cambridge University Press, Cambridge. Lozar, F., Violanti, D., Pierre, F.D., Bernardi, E., Cavagna, S., Clari, P., Irace, A., Martinetto, E. \& Trenkwalder, S. (2010) Calcareous nannofossils and foraminifers Herald the Messinian salinity crisis: the Pollenzo section (Alba, Cuneo; NW Italy). Geobios, 43, 21-32.

Lugli, S., Manzi, V., Roveri, M. \& Schreiber, B.C. (2010)

The primary lower gypsum in the mediterranean: a new facies interpretation for the first stage of the Messinian salinity crisis. Palaeogeogr. Palaeoclimatol. Palaeoecol., 297, 83-99.

Lugli, S., Gennari, R., Gvirtzman, Z., Manzi, V., Roveri, M. \& SCHREIBER, B.C. (2013) Evidence of clastic evaporites in the canyons of the levant Basin (Israel): implications For the Messinian salinity crisis. J. Sediment. Res., 83(11), 942-954.

Malinverno, E., Triantaphyllou, M.V., Stavrakakis, S., ZiVeri, P. \& LyKousis, V. (2009) Seasonal and spatial variability of coccolithophore export production at the South-western margin of Crete (Eastern Mediterranean). Mar. Micropaleontol., 71, 131-147.

Manzi, V., Lugli, S., Ricci Lucchi, F. \& Roveri, M. (2005)

Deep-water clastic evaporites deposition in the Messinian Adriatic foredeep (northern Apennines, Italy): did the Mediterranean ever dry out? Sedimentology, 52(4), 875-902. Manzi, V., Roveri, M., Gennari, R., Bertini, A., Biffi, U., Giunta, S., Iaccarino, S.M., Lanci, L., Lugli, S., Negri, A., Riva, A., Rossi, M.E. \& Taviani, M. (2007) The deep-water counterpart of the Messinian Lower Evaporites in the Apennine foredeep: the Fanantello section (Northern Apennines, Italy). Palaeogeogr. Palaeoclimatol. Palaeoecol., 251(3-4), 470-499.

Manzi, V., Lugli, S., Roveri, M. \& Schreiber, B.C. (2009) A new facies model for the Upper Gupsum of Sicily (Italy): chronological and paleoenvironmental constraints for the Messinian salinity crisis in the Mediterranean. Sedimentology, 56, 1937-1960.

Manzi, V., Lugli, S., Roveri, M., Schreiber, B.C. \& Gennari, R. (2011) The Messinian "Calcare di Base" (Sicily, Italy) revisited. Geol. Soc. Am. Bull., 123(1-2), 347-370.

Manzi, V., Gennari, R., Hilgen, F., Krijgsman, W., Lugli, S., Roveri, M. \& Sierro, F.J. (2013) Age refinement of the Messinian salinity crisis onset in the Mediterranean. Terra Nova, 25(4), 315-322.

Manzi, V., Lugli, S., Roveri, M.,Dela Pierre, F.,Gennari, R., Lozar, F.,Natalicchio, M., Schreiber, B.C., Taviani, M. \& Turco, E. (2015) The Messinian salinity crisis in Cyprus: a further step toward a new stratigraphic framework for Eastern Mediterranean. Basin Res., doi: 10.1111/bre.12107.

MARTINI, E. (1971) Standard tertiary and quaternary calcareous nannoplankton zonation. In: Proceedings of the 2nd Planktonic Conference (Ed. by A. Farinacci), pp. 739-777. Edizioni Tecnioscienza, Rome.

Matano, F., Critelli, S., Barone, M., Muto, F. \& di Nocera, S. (2014) Stratigraphic and provenance evolution of the Southern Apennines foreland basin system during the Middle Miocene to Pliocene (Irpinia-Sannio successions, Italy). Mar. Pet. Geol., 57, 652-670.

MauchiLNE, J. (1988) Growth and breeding of meso- and bathypelagic organisms of the Rockall Trough, northeastern Atlantic Ocean and evidence of seasonality. Mar. Biol., 98, 
387-393.

Meijer, P.T.H. \& Krijgsman, W. (2005) A quantitative analysis of the desiccation and re-filling of the Mediterranean during the Messinian salinity crisis. Earth Planet. Sci. Lett., 240 (2), 510-520.

Mertz-Kraus, R., Brachert, T.C., Reuter, M., Galer, S.J.G., Fassoulas, C. \& Iliopoulos, G. (2009) Late Miocene sea surface salinity variability and paleoclimate conditions in the Eastern Mediterranean inferred from coral aragonite d 18 O. Chem. Geol., 262(3-4), 202-216.

Mundy, B.C. (2005) Checklist of the fishes of the Hawaiian Archipelago. Bishop Mus. Bull. Zool., 20, 1-704.

Muus, B.J. \& Nielsen, J.G. (1999) Sea Fish. Scand. Fish. Year

Book, Hedehusene, Denmark, pp. 340.

Mytilineou, C., Politou, C.Y., Papaconstantinou, C., Kavadas, S., D'onghia, G. \& Sion, L. (2005) Deep-water fish

fauna in the Eastern Ionian Sea. Belgian J. Zool., 135, 229-

233.

Nelson, J.S. (2006) Fishes of the World, 4th edn, pp. 600, John

Wiley and Sons Inc., New Jersey.

NikolaOu, C. (1986) Contribution to the knowledge of the Neogene, the geology and the Ionian and pre-Apulian limits in relation to the petroleum geology observations in Strophades, Zakynthos and Kephallinia islands. PhD Thesis, University of Athens, Athens.

Nolf, D. (1985) Otolithi Piscium. In: Handbook of Paleoichthyology (Ed. by H.P. Schultze), vol. 10, pp. 145, Gustav Fischer Verlag, Stuttgart.

Nolf, D. \& Brzobohaty, R. (1994) Fish otoliths as paleobathymetric indicators. Paleontologia i evolucio, 24-25, 255-264.

OBIS (2006) OBIS-extracted Depth Data, Harvested by E.Agbayani July 2006 at www.iobis.org.

Omodeo-Sale, S., Gennari, R., Lugli, S.,Manzi, V. \& Roveri, M. (2012) Tectonic and climatic control on the Late Messinian sedimentary evolution of the Nijar Basin (Betic Cordillera, Southern Spain). Basin Res., 24(3), 314-337.

ORSZAG-SPERBER, F. (2006) Changing perspectives in the concept of "Lago- Mare" in Mediterranean Late Miocene evolution. Sed. Geol., 188-189, 259-277.

Ort_i, F., P_EREZ-L_OPEZ, A., Garcia-Veigas, J., Roselli, L., Cand_ons, D.I. \& P_erez-Valera, F. (2014) Sulfate isotope compositions (d34S, d18O) and strontium isotopic ratios (87Sr/86Sr) of Triassic evaporites in the Betic Cordillera (SE Spain). Rev. Soc. Geol. Espa na, 27(1), 79-89.

PerCh Nielsen, K. (1985) Cenozoic calcareous nannofossils. In: Plankton Stratigraphy (Ed. by H.M. Bolli, J.B. Saunders, K. Perch-Nielsen), pp. 427-554. Cambridge Earth Science Series, Cambridge.

PIERRE, C. \& Rouchy, J. (1990) Sedimentary and diagenetic evolution of Messinian evaporites in the Tyrrhenian Sea (ODP

Leg 107, Sites 652, 653, and 654): petrographic, mineralogical, and stable isotope records. Proceedings of the ocean drilling program, Scientific results, pp. 187-210.

Pierre, C., Caruso, A., Blanc-Valleron, M.-M., Rouchy, J.M. \& ORZSAG-SPERBER, F. (2006) Reconstruction of the paleoenvironmental changes around the Miocene-Pliocene boundary along a West-East transect across the Mediterranean. Sed. Geol., 188-189, 319-340.

Pomoni-Papaioannou, F., Karakitsios, V., Kamberis, E. \& Marnelis, F. (2004) Chevron-type halite and nodular anhydrite in the Triassic subsurface evaporites of the Ionian zone (western Greece). Bull. Geol. Soc. Greece, 36(1), 578-586.

RADE, J. (1975) Scyphosphaera evolutionary trends with special reference to eastern Australia. Micropaleontology, 21, 151164.

Raffi, I., Backman, J., Fornaciari, E., P€Alike, H., Rio, D., LOURENS, L. \& HiLGEN, F. (2006) A review of calcareous nannofossil astrobiochronology encompassing the past 25 million 
years. Quatern. Sci. Rev., 25, 3113-3137.

RICCI LuCCHI, F. (1973) Sedimentologia. Parte I. Materiali e tessiture dei sedimenti. Cooperativa Libraria Universitaria,

Bologna.

RIo, D. \& SPRovieri, R. (1986) Biostratigrafia integrate del PliocenePleistocene inferire Mediterraneo in un'ottica di stratigrafia systematica. Boll. Soc. Paleontol. Italiana, 25, 65-85.

Rio, D., RafFi, I. \& Villa, G. (1990) 32. Pliocene-Pleistocene Calcareous Nannofossil Distribution Patterns in the Western Mediterranean. Proceedings of the Ocean Drilling Program, Scientific Results. 107.

Robertson, A.H.F., Eaton, S., Follows, E.J. \& Payne, A.S. (1995) Depositional processes and basin analysis of Messinian evaporites in Cyprus. Terra Nova, 7, 233-253.

Rouchy, J.M. (1982) La gen_ese des_evaporites messiniennes de M_editerran_ee.M_em. Mus. Nat. Hist. Nat., C, 50, Paris.

Roveri, M. \& MANZI, V. (2006) The Messinian salinity crisis: looking for a new paradigm? Palaeogeogr. Palaeoclimatol. Palaeoecol., 238, 386-398.

Roveri, M., Manzi, V., Bassetti, M.A., Merini, M. \& Ricci LuCCHI, F. (1998) Stratigraphy of the Messinian postevaporitic stage in eastern-Romagna (northern Apennines, Italy).

Giorn. Geol., 60, 119-142.

Roveri, M., Manzi, V., Ricci Lucchi, F. \& Rogledi, S. (2003)

Sedimentary and tectonic evolution of the Vena del Gesso Basin (Northern Apennines, Italy): implications for the onset of the Messinian salinity crisis. Geol. Soc. Am. Bull., 115, 387-405.

Roveri, M.,Manzi, V., Lugli, S., Schreiber, B.C., Caruso, A., Rouchy, J.-M., Laccarino, S.M., Gennari, R. \& Vitale, F.P. (2006) Clastic vs. primary precipitated evaporites in the Messinian Sicilian basins. RCMNS IC Parma 2006 "The Messinian salinity crisis revisited II" post-congress field-trip guidebook. Acta Naturalia De "L'Ateneo Parmense" 42-1, 125-199.

Roveri, M., Lugli, S., Manzi, V. \& Schreiber, B.C. (2008a) The Messinian Sicilian stratigraphy revisited: new insights for the Messinian salinity crisis. Terra Nova, 20(6), 483-488. Roveri, M., Bertini, A., Cosentino, D., di Stefano, A., Gennari, R., Gliozzi, E., Grossi, F., Iaccarino, S.M., Lugli, S., MANZI, V. \& TAVIANI, M. (2008b) A high-resolution stratigraphic framework for the latest Messinian events in the Mediterranean area. Stratigraphy, 5(3-4), 323-342.

Roveri, M., Flecker, R., KriJgsman, W., Lofi, J., Lugli, S., Manzi, V., Sierro, F.J., Bertini, A., Camerlenghi, A., de Lange, G., Govers, R., Hilgen, F.J., Heubscher, C., MeiJer, P.T. \& STOICA, M. (2014a) The Messinian salinity crisis: past and future of a great challenge for marine sciences. Mar. Geol., 352, 25-58.

Roveri, M., Manzi, V., Bergamasco, A., Falcieri, F.M., Gennari, R., Lugli, S. \& SchreIBER, B.C. (2014b) Dense shelf water cascading and Messinian canyons: a new scenario for the Mediterranean salinity crisis. Am. J. Sci., 314, 751-784. Ruggieri, G. (1967) The Miocene and later evolution of the Mediterranean Sea. Aspects of Tethyan Biogeography, System. Assoc. Lond., 7, 283-290.

Selli, R. (1954) Il Bacino del Metauro. Giorn. Geol., 24, 1-294. Shackleton, N.J., Hall, M.A. \& Pate, D. (1995) Pliocene stable isotope stratigraphy of Site 846. ODP Proc., 138, 337355.

Sierro, F.J., Flores, J.A., Zamarre no, I., VazQuez, A., Utrilla, R., Frances, G., Hilgen, F.J. \& Krijgsman, W. (1999) Messinian preevaporite sapropels and precessioninduced oscillations in western Mediterranean climate. Mar.

Geol., 153, 137-146.

Sierro, F.J., Hilgen, F.J., Krijgsman, W. \& Flores, J.A. (2001) The Abad composite (SE Spain): a Mediterranean reference section for the Mediterranean and the APTS. Palaeogeogr. 
Palaeoclimatol. Palaeoecol., 168, 141-169.

Sierro, F.J., Flores, J.A., Franc_es, G. \& VazQuez, A. (2003)

Orbitally controlled oscillations in planktic communities and

cyclic changes in western Mediterranean hydrography during

the Messinian. Palaeogeogr. Palaeoclimatol. Palaeoecol., 190,

289-316.

Sorel, D. (1976) Etude n_eotectonique dans l'arc_eg_een externe occidental,

pp. 200, Th_ese 3e c., Paris XI, Paris.

Sprovieri, R., Sprovieri, M., Caruso, A., Pelosi, N., Bonomo,

S. \& Ferraro, L. (2006) Astronomic forcing on the planktonic

foraminifera assemblage in the Piacenzian Punta Piccola

section (southern Italy). Paleoceanography, 21, PA4204.

di Stefano, A.\&Sturiale, G. (2010) Refinements of calcareous

nannofossil biostratigraphy at the Miocene/Pliocene Boundary

in the Mediterranean region. Geobios, 43, 5-20.

di Stefano, E., Sprovieri, R. \& Scarantino, S. (1996) Chronology

of biostratigraphic events at the base of the Pliocene. Paleopelagos,

6, 401-414.

TriantaPhyllou, M.V. (1996) Biostratigraphical and ecostratigraphical observations based on calcareous nannofossils of the

eastern Mediterranean Plio-Pleistocene deposits. GAIA, 1,

229.

Triantaphyllou, M.V., Drinia, H. \& Dermitzakis, M.D.

(1997) The Plio-Pleistocene boundary in the Gerakas section, Zakynthos (Ionian Islands). Neues Jb. Geol. Pal€aontol. Monat., 1, 12-30.

Triantaphyllou, M.V., Tsaparas, N., Stamatakis, M. \&Dermitzakis,

M.D. (1999) Calcareous nannofossil biostratigraphy

and petrological analysis of the preevaporitic diatomaceous

sediments from Gavdos Island, southern Greece. Neues Jb.

Geol. Pal€aontol. Monat., 3, 161-178.

Triantaphyllou, M.V., Ziveri, P., Gogou, A., Marino, G.,

Lykousis, V., Bouloubassi, I., Emeis, K.-C., Kouli, K.,

Dimiza, M., Rosell-Mele, A., Papanikolaou, M., Katsouras,

G. \& NunEz, N. (2009a) Late Glacial-Holocene climate

variability at the south-eastern margin of the Aegean

Sea. Mar. Geol., 266, 182-197.

Triantaphyllou, M.V., Antonarakou, A., Kouli, K., Dimiza, M., Kontakiotis, G., Papanikolaou, M.D., Ziveri, P.,Mortyn, P.G., Lianou, V., LyKousis, V. \& Dermitzakis, M.D.

(2009b) Late Glacial-Holocene ecostratigraphy of the southeastern Aegean Sea, based on plankton and pollen assemblages.

Geo. Mar. Lett., 29(4), 249-267.

Tsapralis, V. (1981). Contribution to the study of the Pleistocene of Zakynthos Island, W. Greece (Ostracoda - Paleoenvironment). $\mathrm{PhD}$ Thesis, Patras.

UNDERHILL, J.R. (1989) Late Cenozoic deformation of the Hellenide foreland, western Greece. Geol. Soci. Am. Bull., 101,

513-634.

VAI, G.B. (1997) Cyclostratigraphic estimate of the Messinian stage duration. In: Miocene Stratigraphy: An Integrated Approach, Developments in Paleontology and Stratigraphy (Ed. by Montanari A., Odin G.S. \& Coccioni R. ), 15, 463-476. Van der LaAn, E., Gaboardi, S., Hilgen, F. \& Lourens, L. (2005) Regional climate and glacial control on high-resolution oxygen isotope records from Ain El Beida (Latest

Miocene, Northwest Morocco): a cyclostratigraphic analysis in the depth and time domain. Paleoceanography, 20,

doi: 10.1029/2003PA000995.

Wacey, D., Kilburn, M.R., Mcloughlin, N., Parnell, J., StoAkes, C.A., Governor, C.R.M. \& Brasier, M. (2008) Use of NanoSIMS in the search for early life on Earth: ambient inclusion trails in a ca. 3400 Ma sandstone. J. Geol. Soc.

Lond., 165, 43-53.

WADE, B.S. \& Bown, P.R. (2006) Calcareous nannofossils in extreme environments: the Messinian salinity crisis, Polemi Basin, Cyprus. Palaeogeogr. Palaeoclimatol. Palaeoecol., 233 (3-4), 271-286. 
WHEELER, A. (1992) A list of the common and scientific names of fishes of the British Isles. J. Fish Biol., 41(1), 1-37.

Young, J.R. (1994) Functions of coccoliths. In: Coccolithophores (Ed. by A. Winter, W.G. Siesser), pp. 63-82. Cambridge

University Press, Cambridge.

Zelilidis, A., Kontopoulos, N., Avramidis, P. \& Piper, D.J.W.

(1998) Tectonic and sedimentological evolution of the Pliocene-

Quaternary basins of Zakynthos Island, Greece: case

study of the transition from compressional to extensional tectonics.

Basin Res., 10(4), 393.

Ziveri, P., Baumann, K.H., Bєockel, B., Bollmann, J. \&

Young, J. (2004) Biogeography of selected coccolithophores

in the Atlantic Ocean, from Holocene sediments. In: Coccolithophores:

From Molecular Processes to Global Impact (Ed. by

H. Thierstein \& J. Young), pp. 403-428. Springer Verlag,

Berlin, Heidelberg. 

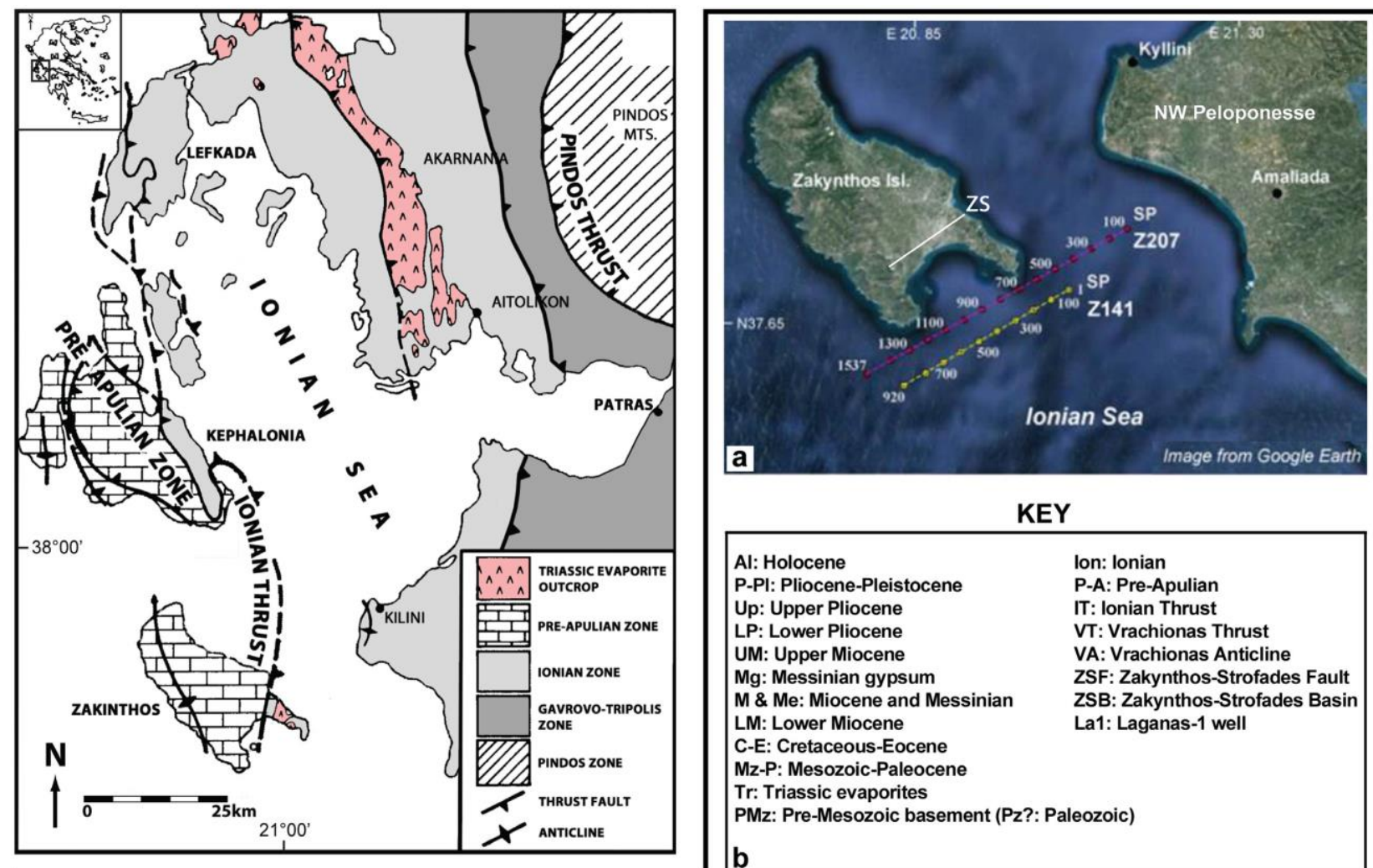

\begin{tabular}{|ll|}
\multicolumn{2}{c}{ KEY } \\
\hline Al: Holocene & Ion: Ionian \\
P-PI: Pliocene-Pleistocene & P-A: Pre-Apulian \\
Up: Upper Pliocene & IT: Ionian Thrust \\
LP: Lower Pliocene & VT: Vrachionas Thrust \\
UM: Upper Miocene & VA: Vrachionas Anticline \\
Mg: Messinian gypsum & ZSF: Zakynthos-Strofades Fault \\
M \& Me: Miocene and Messinian & ZSB: Zakynthos-Strofades Basin \\
LM: Lower Miocene & La1: Laganas-1 well \\
C-E: Cretaceous-Eocene & \\
Mz-P: Mesozoic-Paleocene & \\
Tr: Triassic evaporites & \\
PMz: Pre-Mesozoic basement (Pz?: Paleozoic) \\
b
\end{tabular}
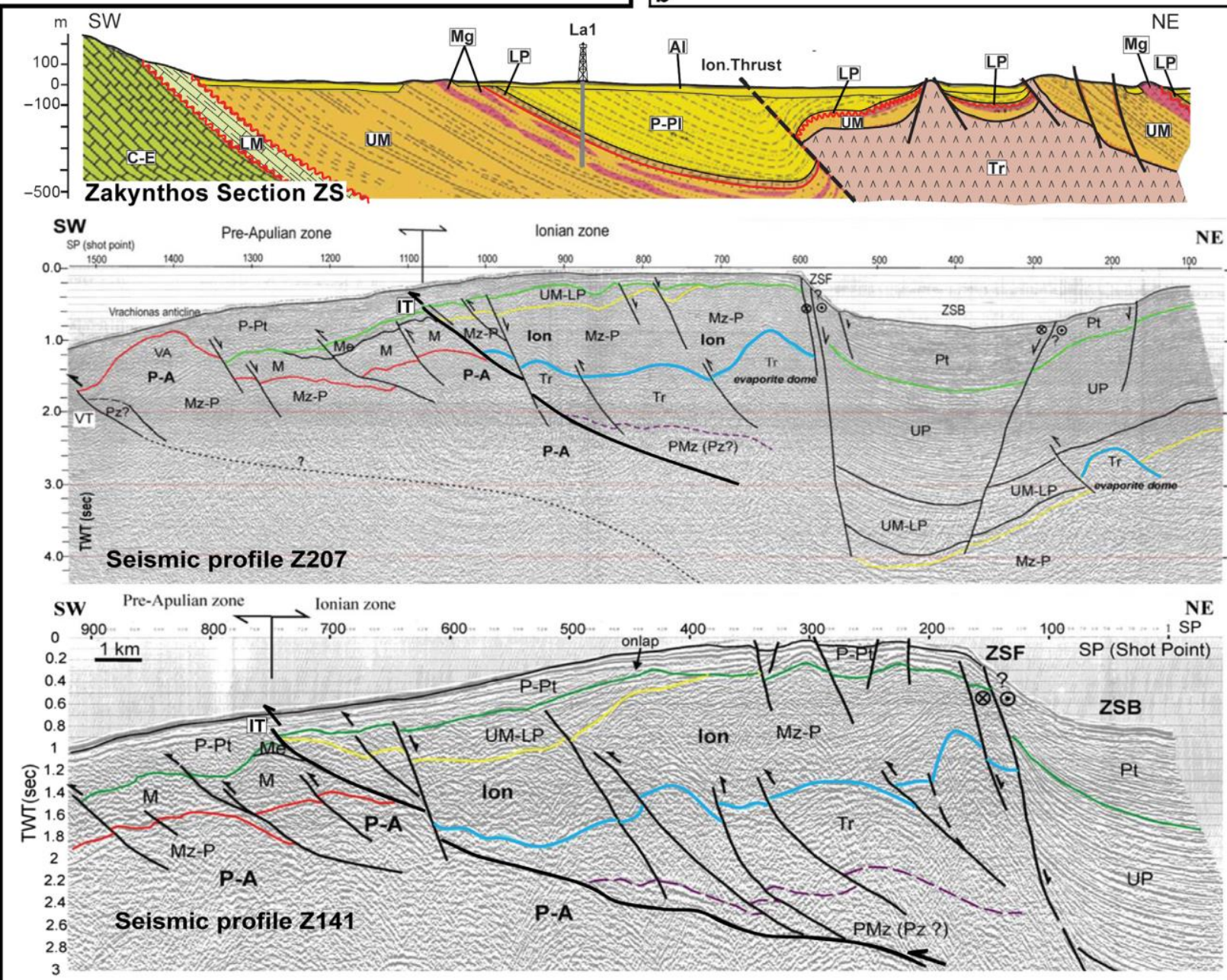

Fig. 1. (A) Regional map of western Greece and the Ionian Islands, showing the close link between the Triassic evaporites and the 
thrust boundaries. (B). Zakynthos onshore and south Zakynthos offshore sections: a) Google Earth map with the location of the sections, b) sections symbols, c) onshore Zakynthos section ZS, d) interpreted offshore seismic profile Z-207, and e) interpreted offshore seismic profile Z-141. Both seismic profiles ( $\mathrm{d} \&$ e) extend through the Ionian (Ion) and the pre-Apulian (P-A) zones (after Kokkalas et al., 2013, modified).

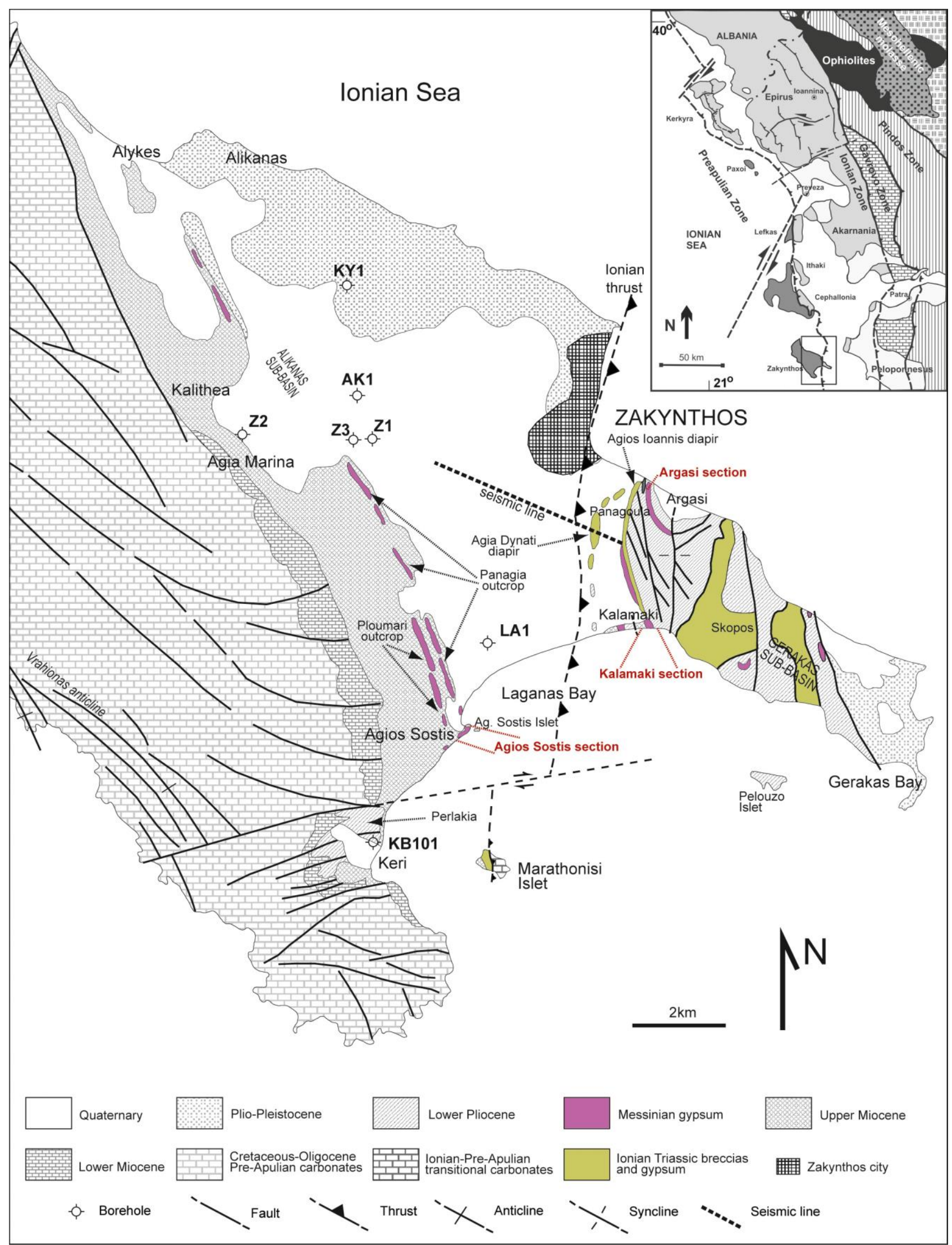


Fig. 2. Geological map of Zakynthos Island. The regional location is indicated in the inset map. Boreholes: Z1 (Zakynthos-1); Z2 (Zakynthos-2), Z3 (Zakynthos-3); LA1 (Laganas-1); KB101 (Keri-well), AK1 (Agios Kyrikos-1), KY1 (Kypseli-1).

\section{SECTION WEST (pre-MSC)}

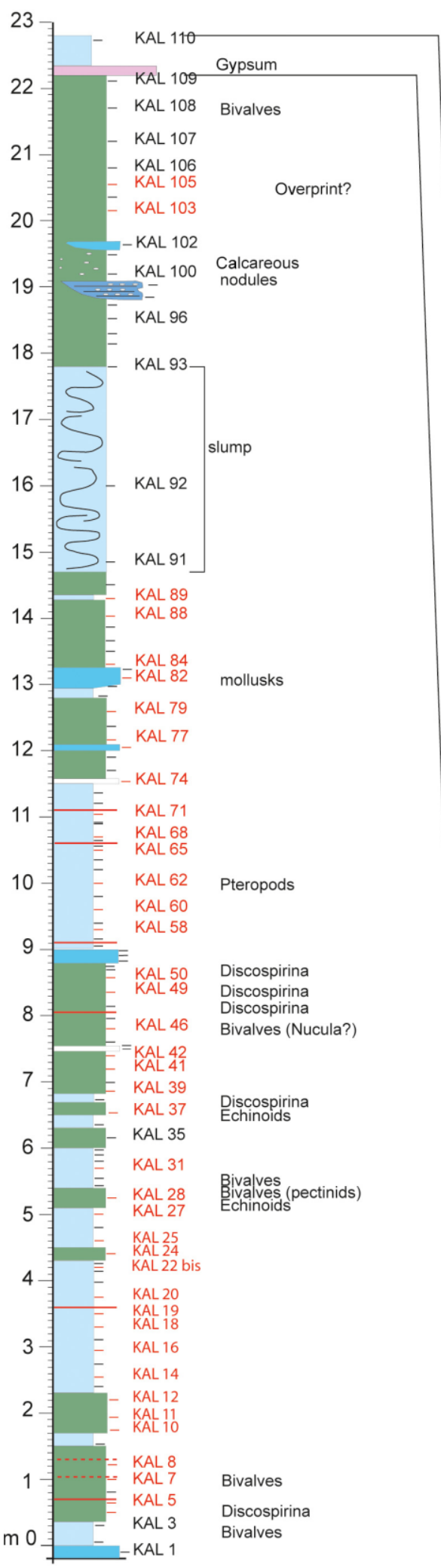

CENTRAL SECTION (evaporites)

SECTION EAST (Messinian/Zanclean)

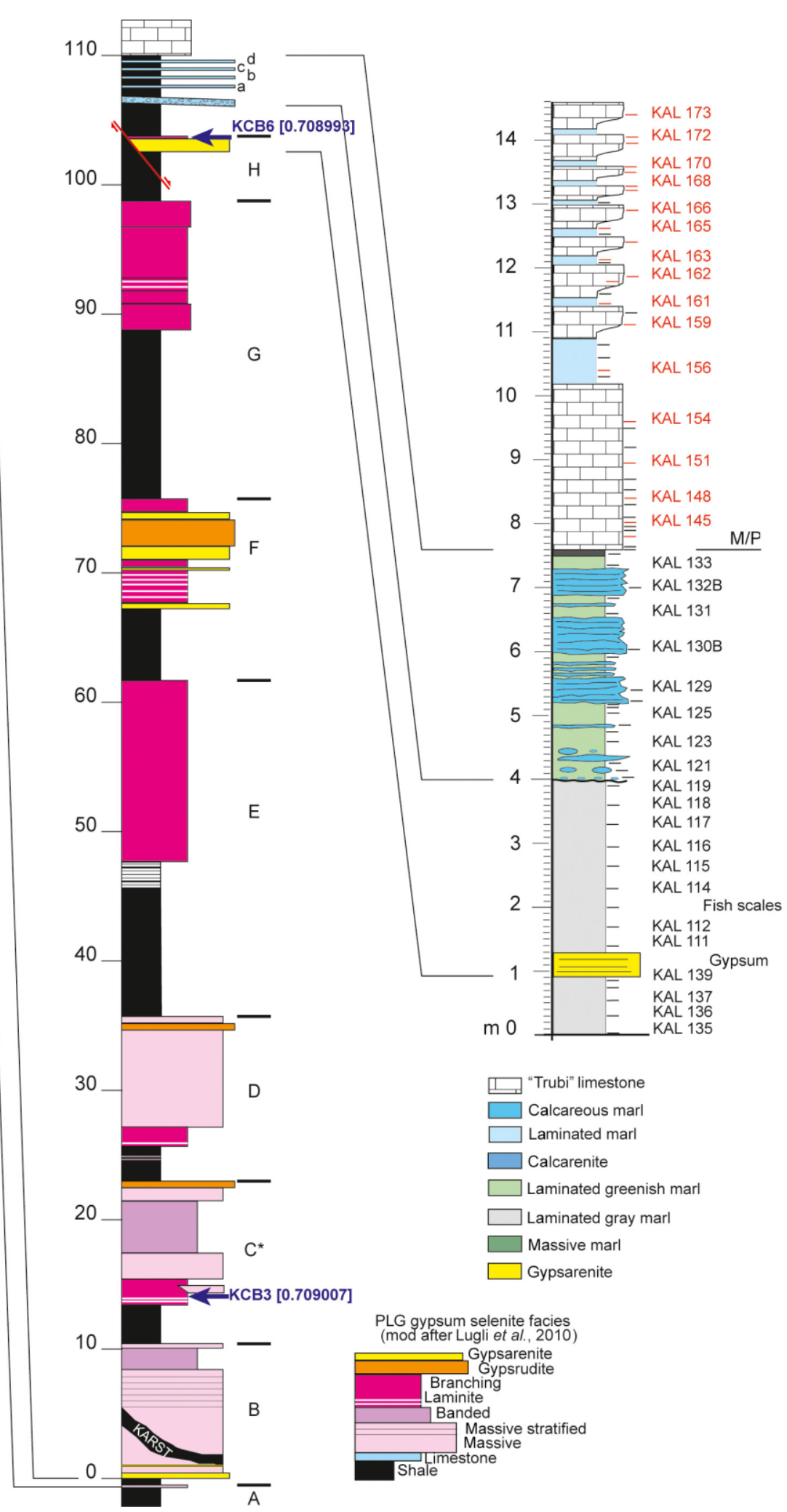

Fig. 3. Kalamaki composite section (west subsection: $37^{\circ} 44011.95^{\prime \prime} \mathrm{N}, 20^{\circ} 54013.14^{\prime \prime} \mathrm{E}$; east subsection: $37^{\circ} 44012.62^{\prime \prime} \mathrm{N}$, $20^{\circ} 54019.09^{\prime \prime} \mathrm{E}$ ) 
with lithology, samples' location, macrofossils of the pre-evaporitic sequence, the evaporitic unit (the PLG facies description is referred in the key), the top of the evaporitic unit, and the post-evaporitic sequence, and two Sr isotope values from the base and the top of the gypsum unit). M/P: Miocene/Pliocene boundary, pre-MSC: pre-Messinian Salinity Crisis part of the section, MES: Messinian Erosional Surface, samples KAL 1 to KAL 173 with their position in the section.

\section{AGIOS SOSTIS COMPOSITE SECTION}

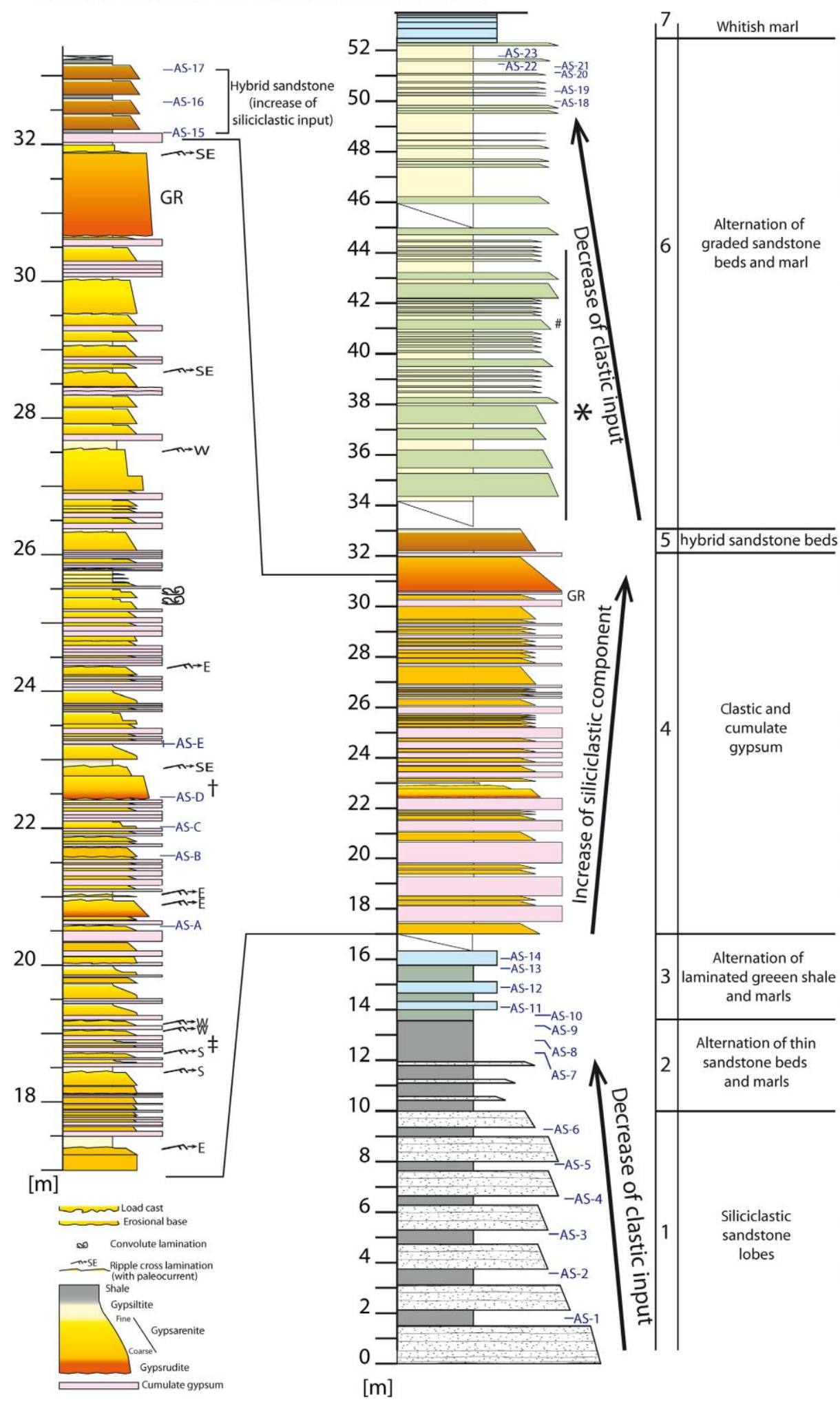

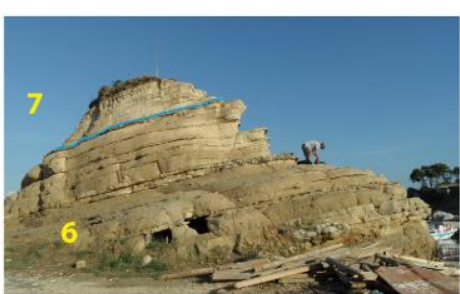
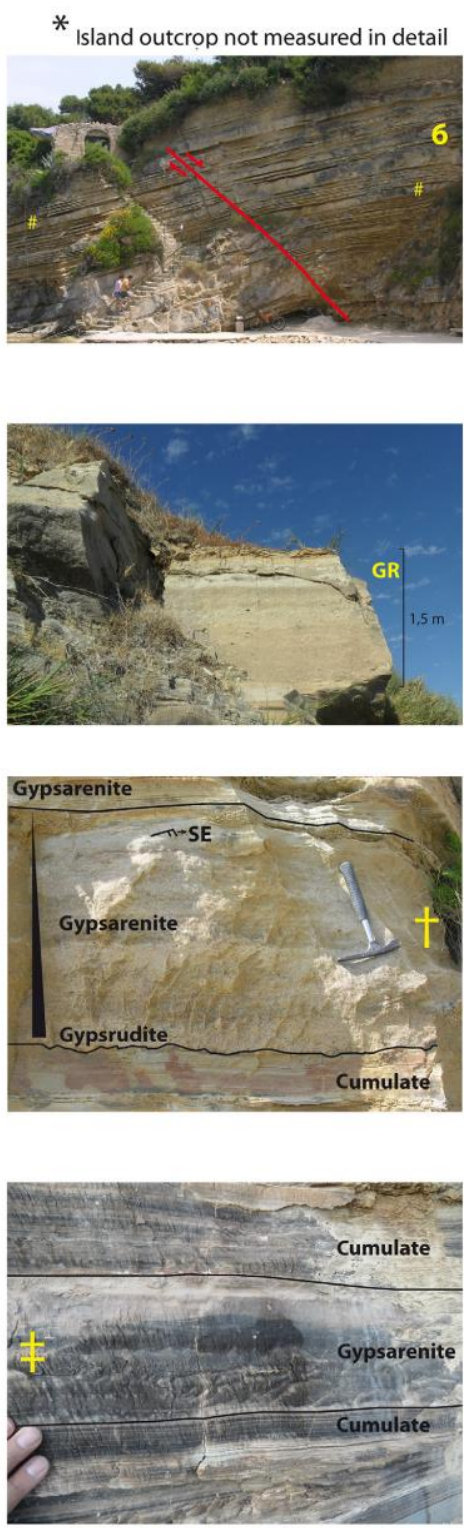

Fig. 4. The Agios Sostis composite section: lithology, samples' location, and facies characteristics of the different stratigraphic levels. 


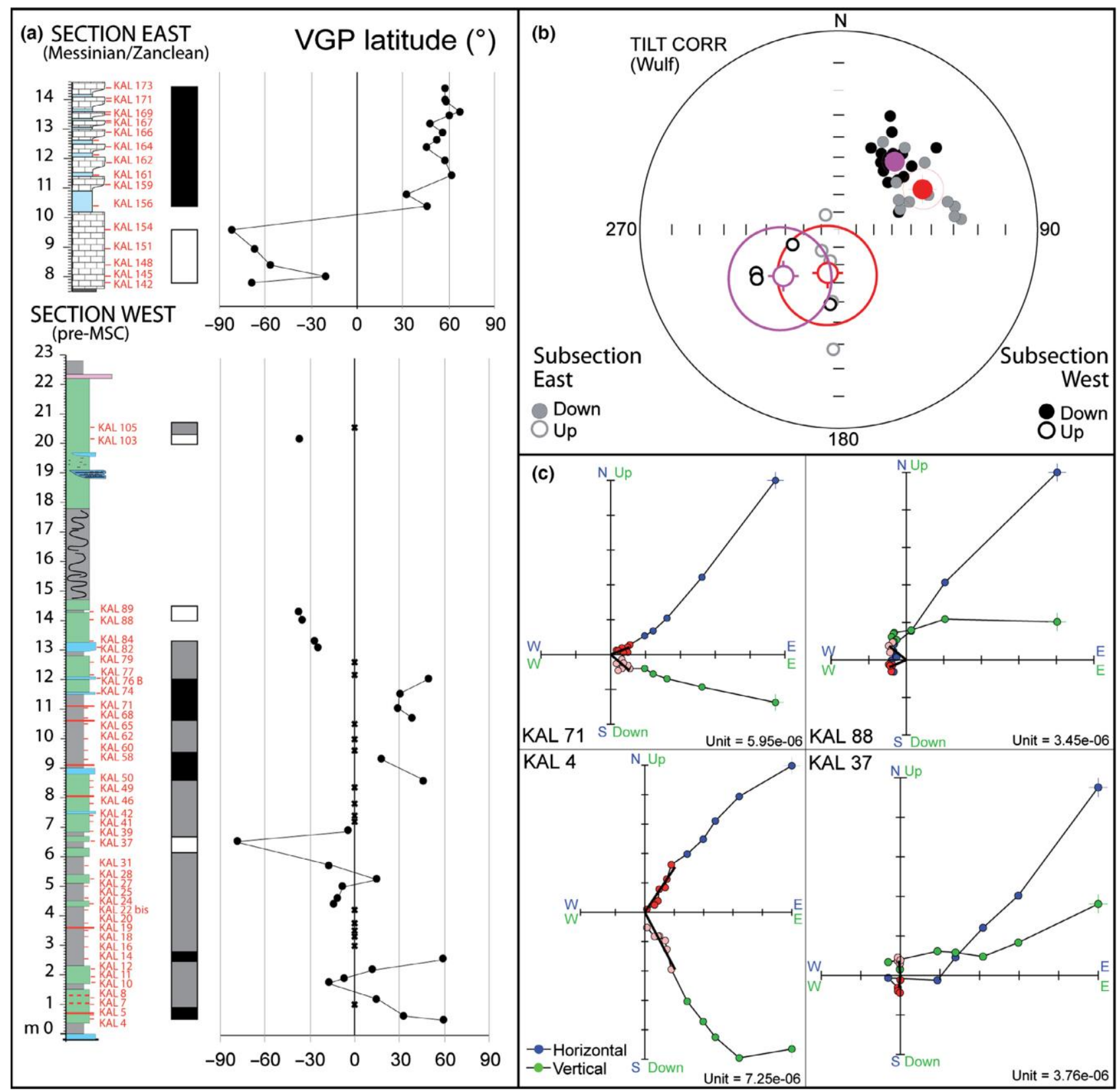

Fig. 5. (a) Plots of VGP latitude of the western and the eastern Kalamaki subsections. (b) Plots of ChRM directions corrected for bed tilting, full and empty red and purplr circles represent normal and reversed mean direction for the Kalamaki western and eastern subsection, respectively. (c) Zijderveld diagrams with demagnetization paths of selected samples from the Kalamaki west subsection. 

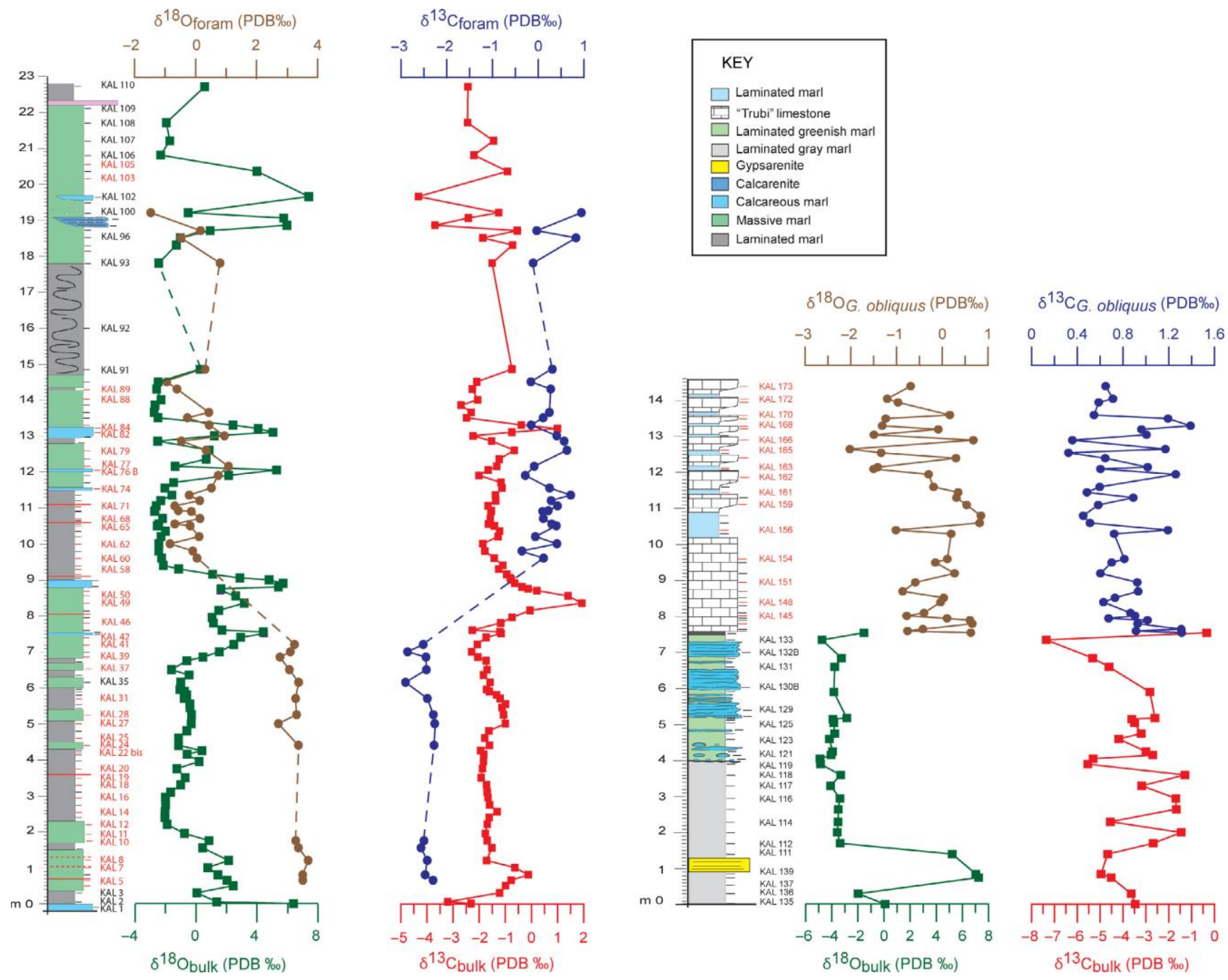

Fig. 6. Kalamaki section carbon and oxygen stable isotopes of the pre-evaporitic sequence, PLG top portion, Lago Mare, and Trubi Formation. The subscript 'foram' in Messinian Oforam and Cforam corresponds to undifferentiated O. universa (9.6-19.5 m) and T. multiloba $(0-7 \mathrm{~m})$, depending on the availability. (full data are available as supplementary material). 

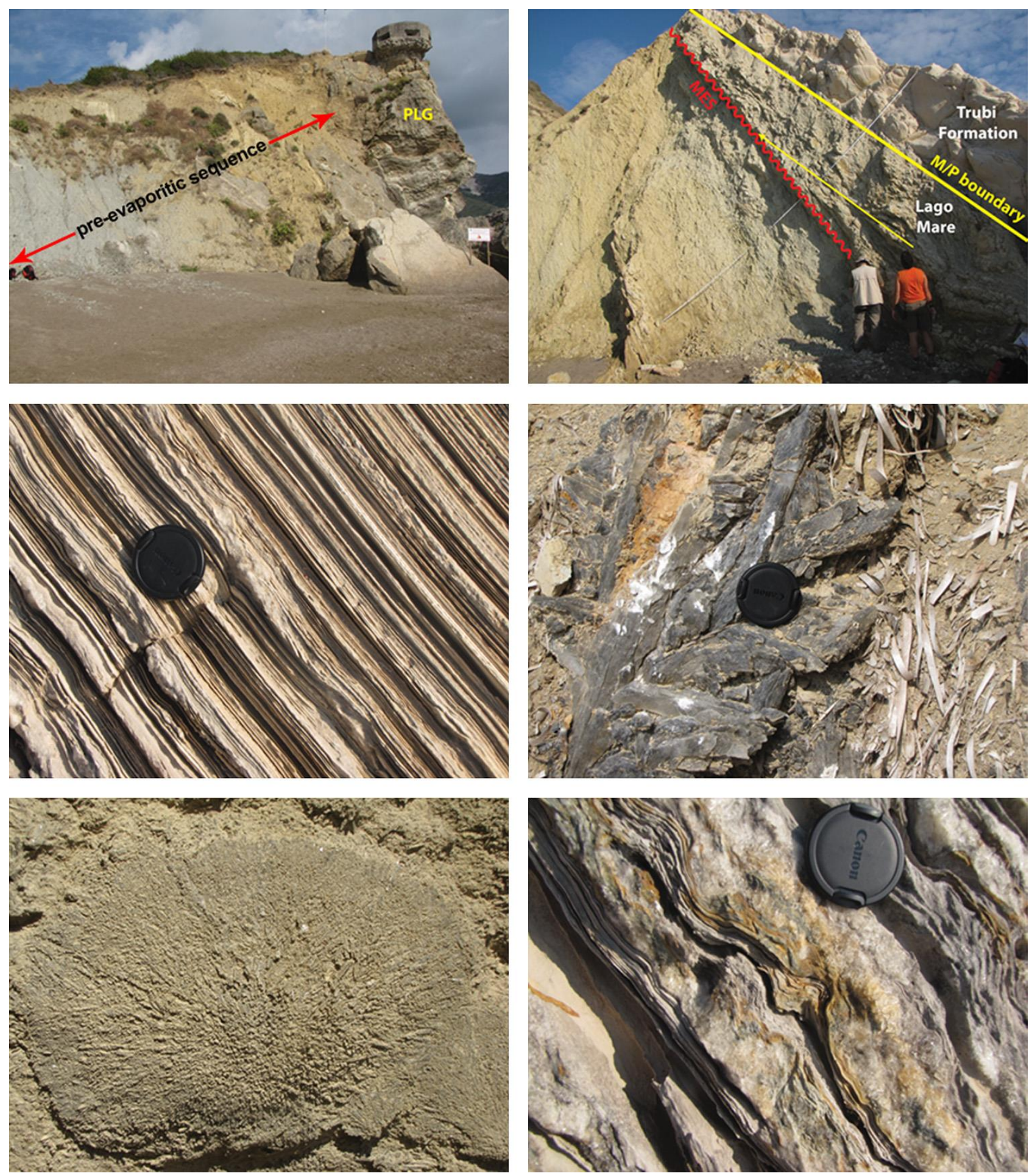

Fig. 7. The Kalamaki section's facies detail. (a) Pre-evaporitic sequence, PLG: Primary Lower Gypsum; (b) uppermost portion of the Primary Lower Gypsum unit topped by the Lago Mare unit, and by the Trubi Formation: Lago Mare stratification is overlapping (yellow arrow) the MES (Messinian Erosional Surface); (c) gypsum laminite; (d) swallow- tail gypsum selenites; (e) bottom view of a branching selenite cone; (f) branching selenite facies. 


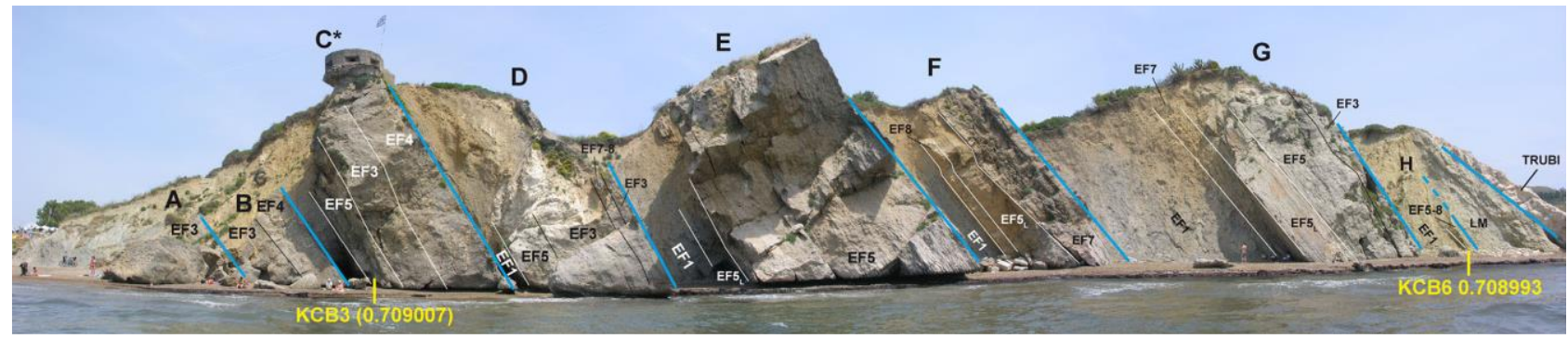

Fig. 8. Kalamaki section Primary Lower Gypsum (PLG) unit. Letters A to H: correspond to the eight cycles of depositional gypsum types observed in the PLG unit. The last cycle H corresponds to top of the PLG unit showed in Fig. 3b, is overlain by the Lago Mare (LM) unit through a low-angle unconformity. Evaporite facies of the PLG unit: EF1: Shale, EF2: Limestone, EF3: massive selenite, EF4: banded selenite, EF5: branching selenite (EF5L: gypsum laminite), EF7: gypsrudite, EF8: gypsarenite (see also key of Fig. 2). 

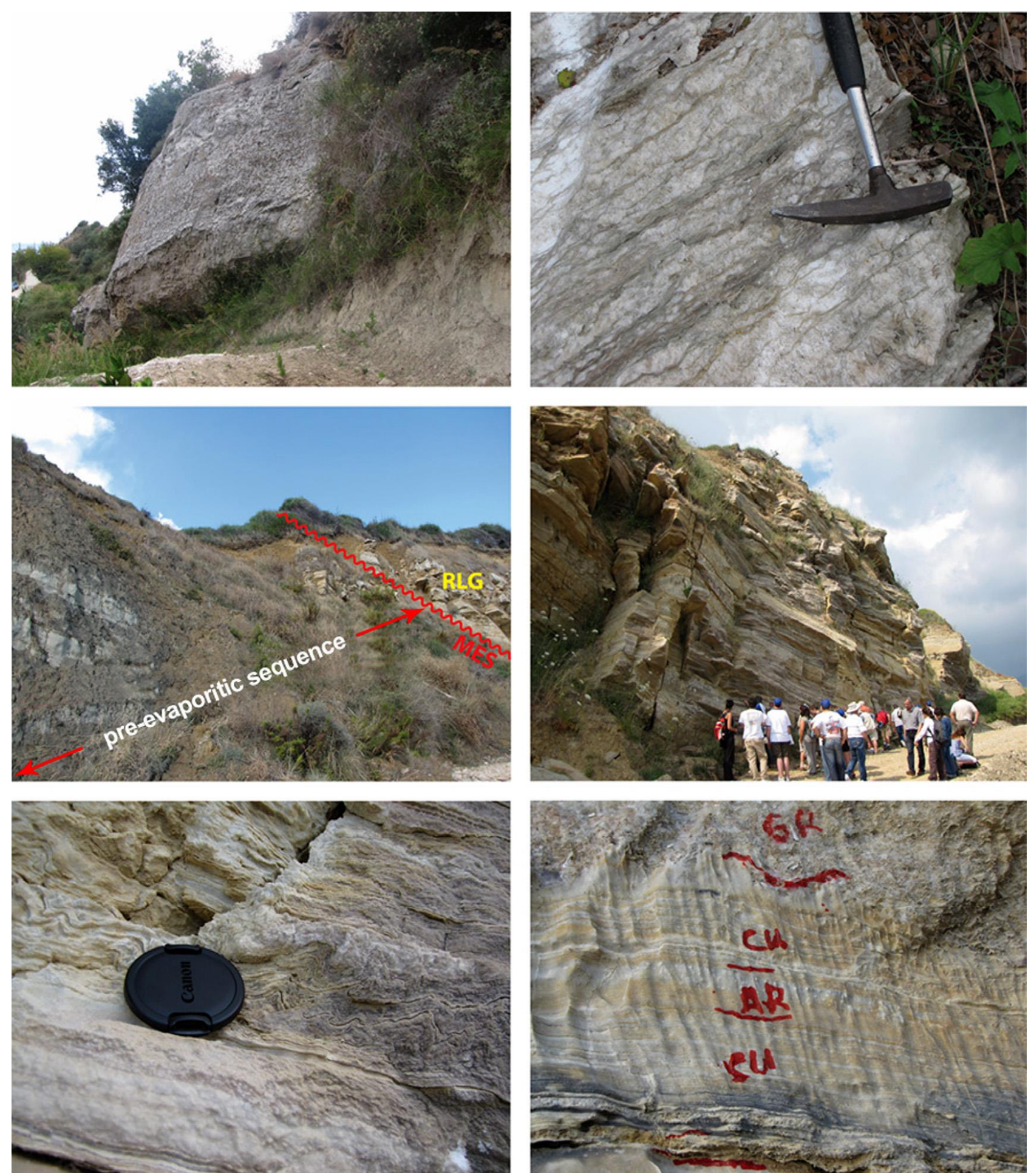

Fig. 9. Sedimentary facies details of the PLG and RLG units. Argassi area: (a) selenite, (b) branching selenite. The Agios Sostis area: (c) pre-evaporitic sequence and MES boundary or sliding surface with the overlying RLG unit, (d) gypsum turbidites, (E) convolute lamination, (F) alternations of primary cumulate gypsum (CU) and clastic gypsarenite (AR) and gypsrudite (GR). 


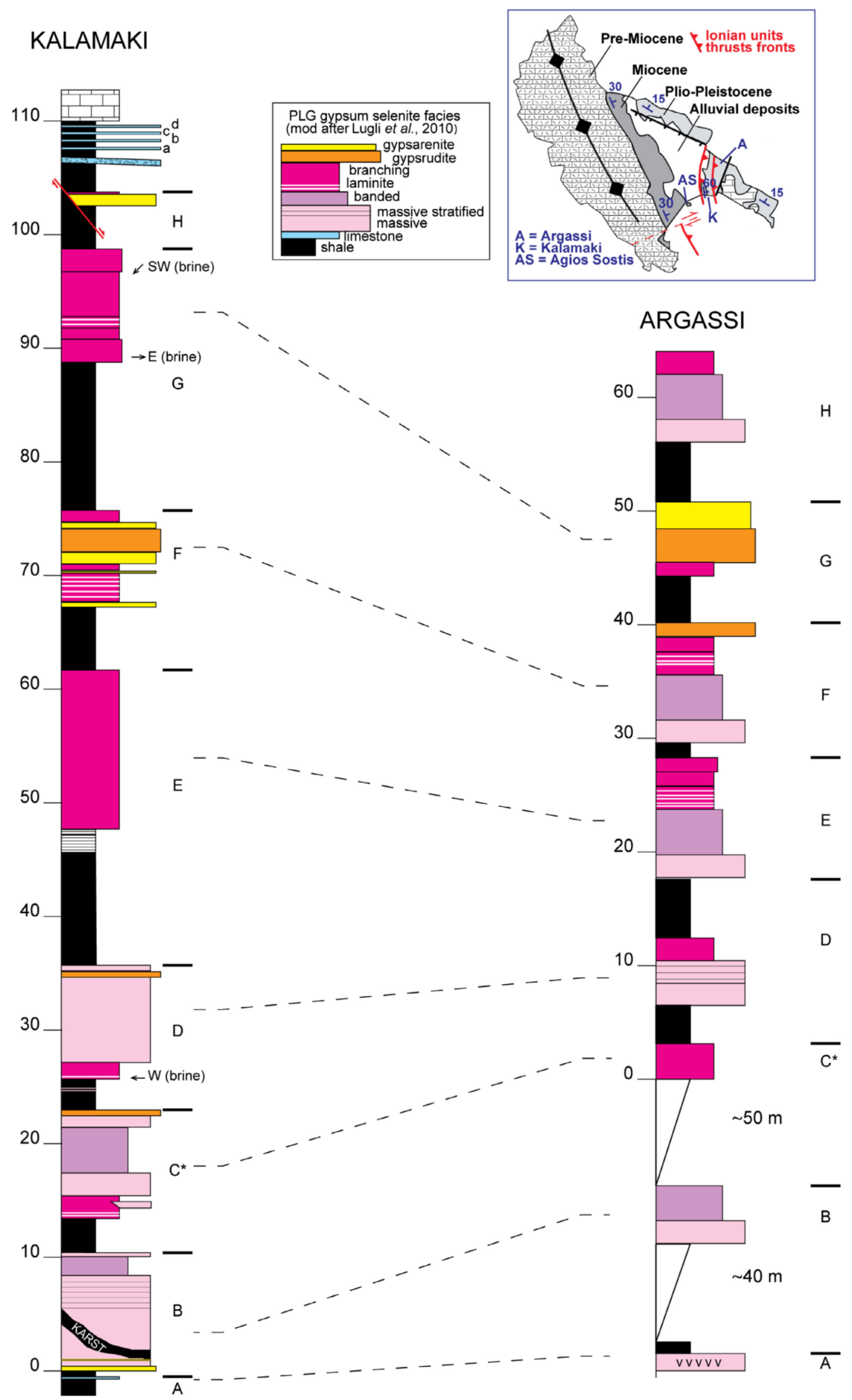

Fig. 10. Kalamaki-Argassi Primary Lower Gypsum unit correlation. 


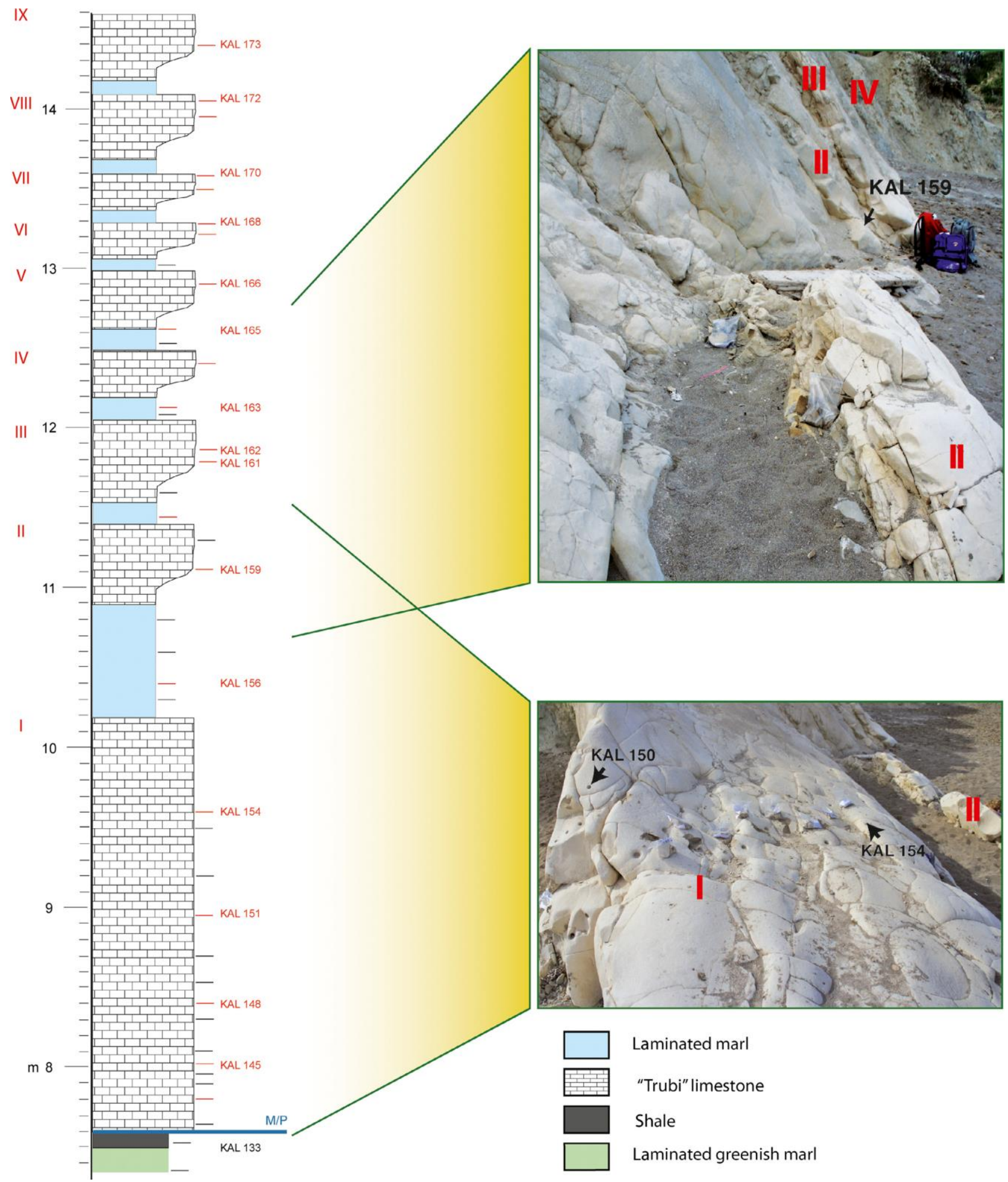

Fig. 11. Kalamaki section Trubi Formation facies. Based on lithology, nine cycles (I to IX) of marly limestones alternating with marls are observed. 


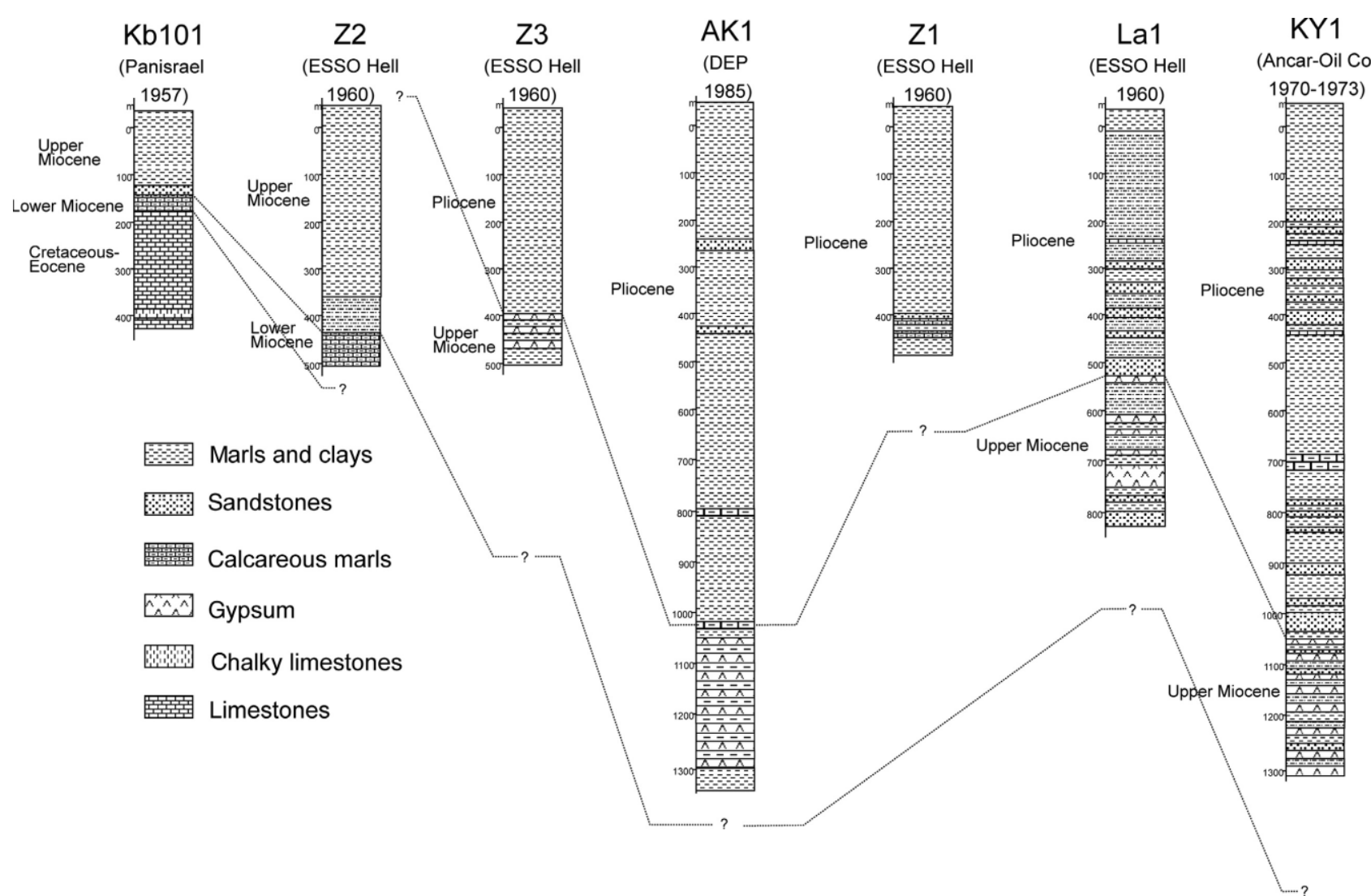

Fig. 12. Zakynthos (Alikanas) basin wells (their location is indicated in Fig. 2). The borehole logs are projected to a line parallel to the dipping of the Alikanas monocline (Figs 1 and 2) to enable correlating the Miocene-Pliocene deposits' lateral evolution.

However, we cannot recognize the thickness distribution from the well logs, because there are no available stratigraphic datums.

Therefore, we use only the two western logs to observe the reduced thickness of the lower Miocene sequence (Kb101) and its gradual thickening towards the immediately eastern $\log (\mathrm{Z} 2)$. 


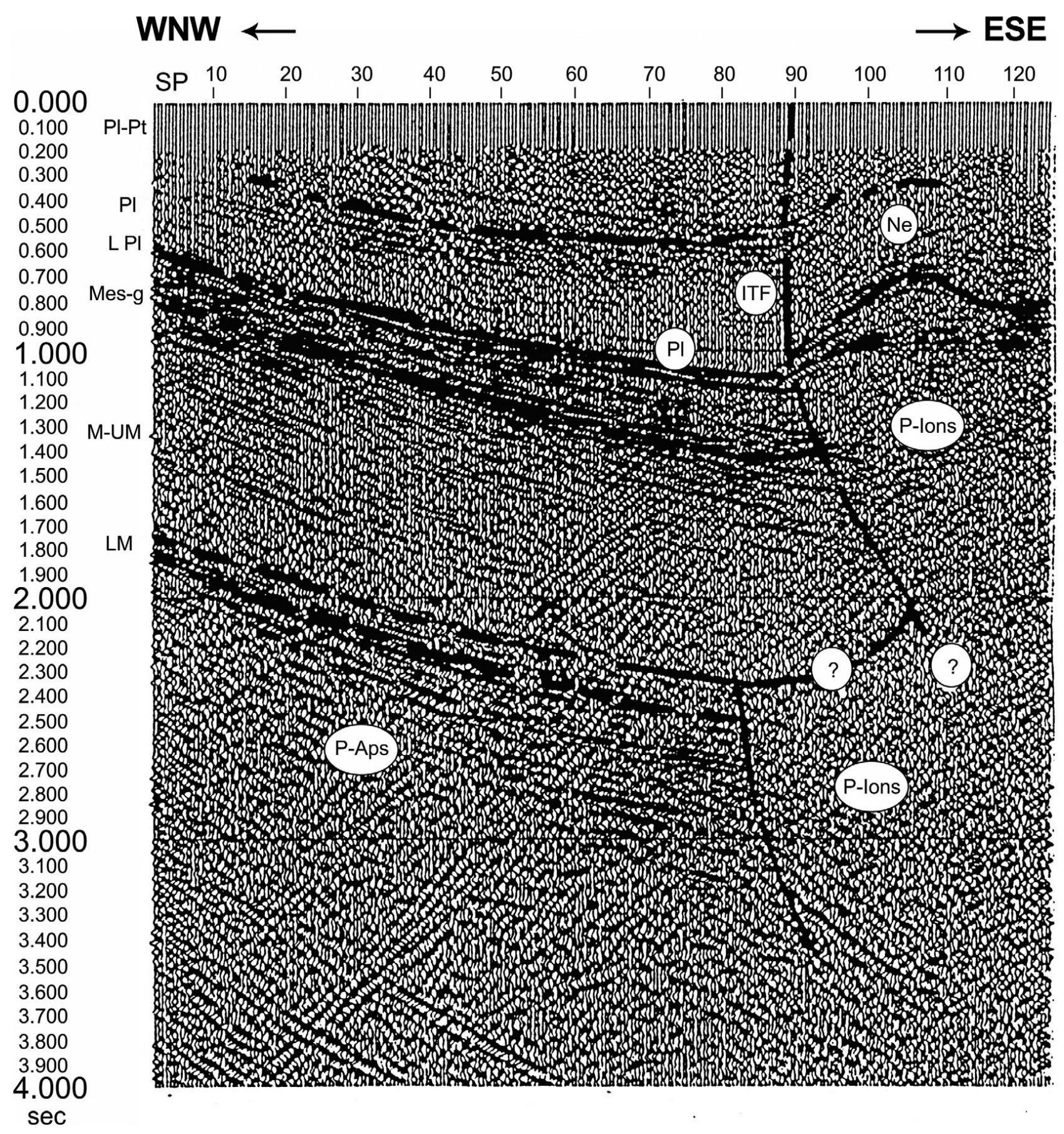

Fig. 13. Seismic profile performed in the eastern half of Zakynthos (Alikanas) basin (modified from the initial representation by Marinescu; in Nikolaou, 1986). The seismic profile shows (a) the position of the Ionian thrust, (b) the eastward increase in the thickness of the Neogene deposits (Messinian gypsum included). The seismic line's location is indicated in Fig. 2. PL-PT: PliocenePleistocene, Pl: Pliocene, LPl: lower Pliocene, Mes-g: Messinian gypsum, M-UM: middleupper Miocene, LM: lower Miocene, P-Aps: pre-Neogene sequence of the pre-Apulian zone, P-Ions: pre-Neogene sequence of the Ionian zone (Triassic evaporites), ITF: Ionian thrust front, Ne: undifferentiated Neogene, SP: 


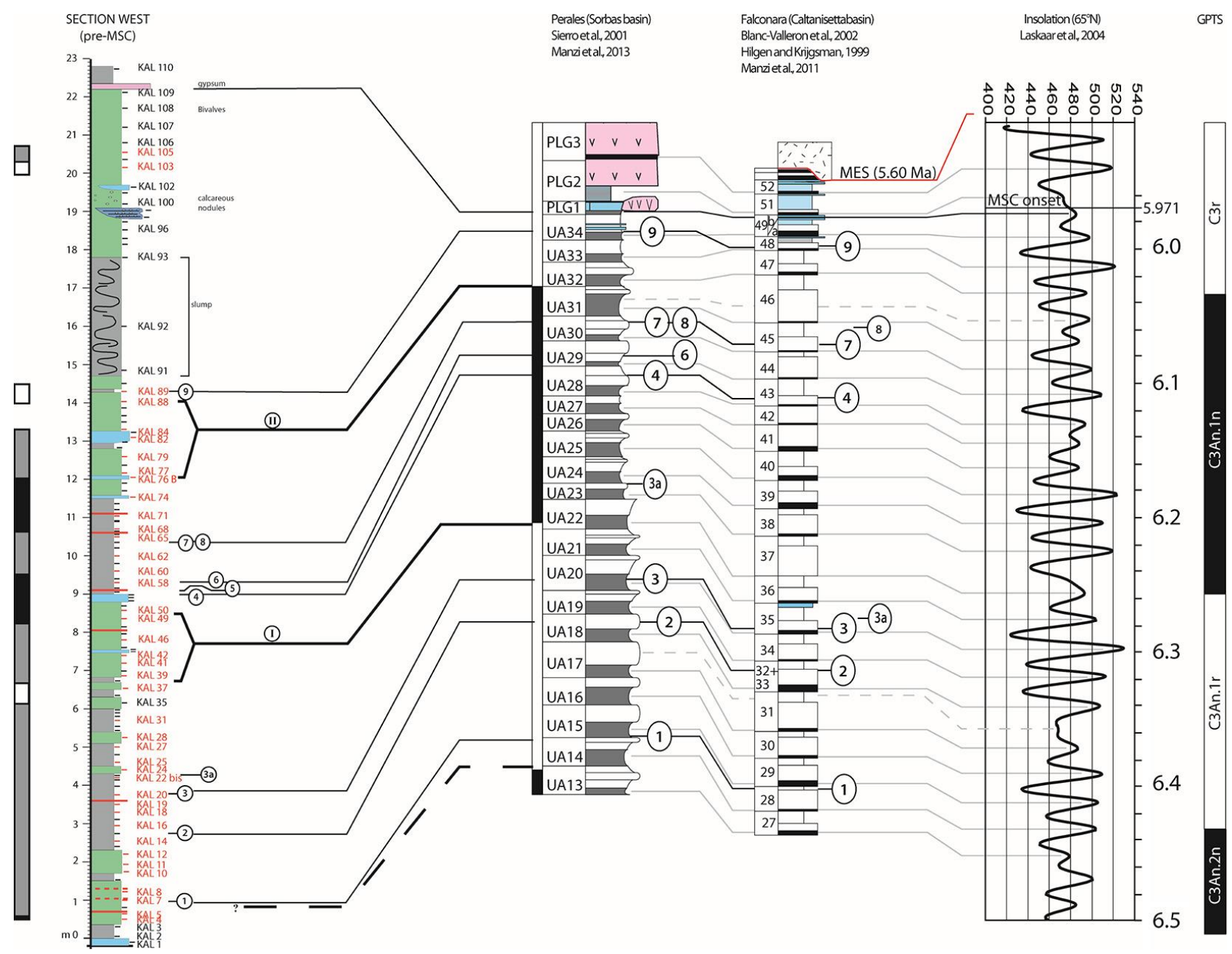

Fig. 14. Chronostratigraphic framework of Kalamaki section's pre-evaporitic sequence and correlation with Perales section (Sorbas Basin) (modified after Sierro et al., 2001; Manzi et al., 2013) and Falconara section (Caltanissetta Basin) (modified after BlancValleron et al., 2002; Hilgen \& Krijgsman, 1999; Manzi et al., 2011) via the astronomical Insolation summer curve of Laskar et al. (2004) and GPTS of Lourens et al. (2004). Bio-magnetostratigraphic events are as follows: 1) FAO T. multiloba; 2) FAO dextral N. acostaensis; 3) G. scitula influx; 4) N. acostaensis dominance sinistral; 5) T. multiloba influx; 6) G. scitula influx; 7) dominance N. acostaensis sinistral; 8) Last abundant influx T. multiloba; 9) HO planktonic Foraminifera; I) top C3An.1n; II) boundary C3An.2n/C3r. 


\begin{tabular}{|c|c|c|c|}
\hline Family & Genus/Species & Ecology & References \\
\hline Gonostomatidae & Indet. & - & - \\
\hline Sternoptychidae & Maurolicus muelleri (Gmelin, 1789) & $\begin{array}{l}0-1524 \mathrm{~m} \text {, usually } 300-400 \mathrm{~m} \text {; } \\
\text { SP-Tr; marine, bathypelagic }\end{array}$ & $\begin{array}{l}\text { Mauchilne (1988); } \\
\text { Wheeler (1992) }\end{array}$ \\
\hline Phosichthyidae & Vinciguerria pomeriae (Сocco, 1838) & $\begin{array}{l}50-1000 \mathrm{~m} \text {, usually } 300-600 \mathrm{~m} \text {; } \\
\text { ST-Tr; marine, bathypelagic }\end{array}$ & Mundy (2005) \\
\hline \multirow[t]{7}{*}{ Myctophidae } & Ceratoscopelus maderensis (Lowe, 1839) & 51-1082 m; Te; marine, bathypelagic & $\begin{array}{l}\text { Hulley (1990); } \\
\text { Mytilineou et al. } \\
\text { (2005) }\end{array}$ \\
\hline & Diaphus cavallonis Brzobohaty and Nolf, $2000 *$ & - & - \\
\hline & Diaphus cf. pedemontanus Robba, 1970 * & - & - \\
\hline & Diaphus rafinesquii $($ Cocco, 1838$)$ & 40-1200 m; Te; marine, bathypelagic & Hulley (1990) \\
\hline & Diaphus rubus Girone et al., 2010 * & - & - \\
\hline & Diaphus taaningi Norman, 1930 & 40-475 m; Tr; marine, bathypelagic & Hulley (1990) \\
\hline & Myctophum coppa Girone et al., 2010* & - & - \\
\hline Moridae & Physiculus aff. huloti Polli, 1953 & 92-320 m; Tr; marine, benthopelag. & OBIS (2006) \\
\hline \multirow[t]{2}{*}{ Gadidae } & Gadiculus argenteus Guichenot, 1850 & $\begin{array}{l}\text { 100-1000 m; Te-ST; marine, } \\
\text { pelagic-oceanic }\end{array}$ & $\begin{array}{l}\text { Muus \& Nielsen } \\
\text { (1999) }\end{array}$ \\
\hline & Gadiculus labiatus (Schubert, 1905) * & - & - \\
\hline Gobiidae & Indet. & - & - \\
\hline Trichiuridae & Lepidopus caudatus (Euphrasen, 1788) & $42-620 \mathrm{~m}$, usually $100-300 \mathrm{~m} ; \mathrm{ST}-\mathrm{Te}$ & $\begin{array}{l}\text { Mytilineou et al. } \\
\text { (2005) }\end{array}$ \\
\hline Soleidae & Buglossidium sp. & 5-450 m, usually $10-40 \mathrm{~m}$; ST & $\begin{array}{l}\text { Muus \& Nielsen } \\
\text { (1999) }\end{array}$ \\
\hline
\end{tabular}

Table 1. The identified Teleost fish taxa in the pre-evaporitic Messinian of Kalamaki section. Taxa in bold are not present in the modern Mediterranean. Taxa marked with an asterisk are presently extinct. Present-day ecological data and the corresponding references are presented for the extant taxa. Climatic zone distributions are abbreviated as follows: Tr. Tropical, ST. Subtropical, Te. Temperate, SP. Subpolar. The modern ecology of Buglossidium sp. refers to its only present-day representative, B. luteum (Risso, 1810)

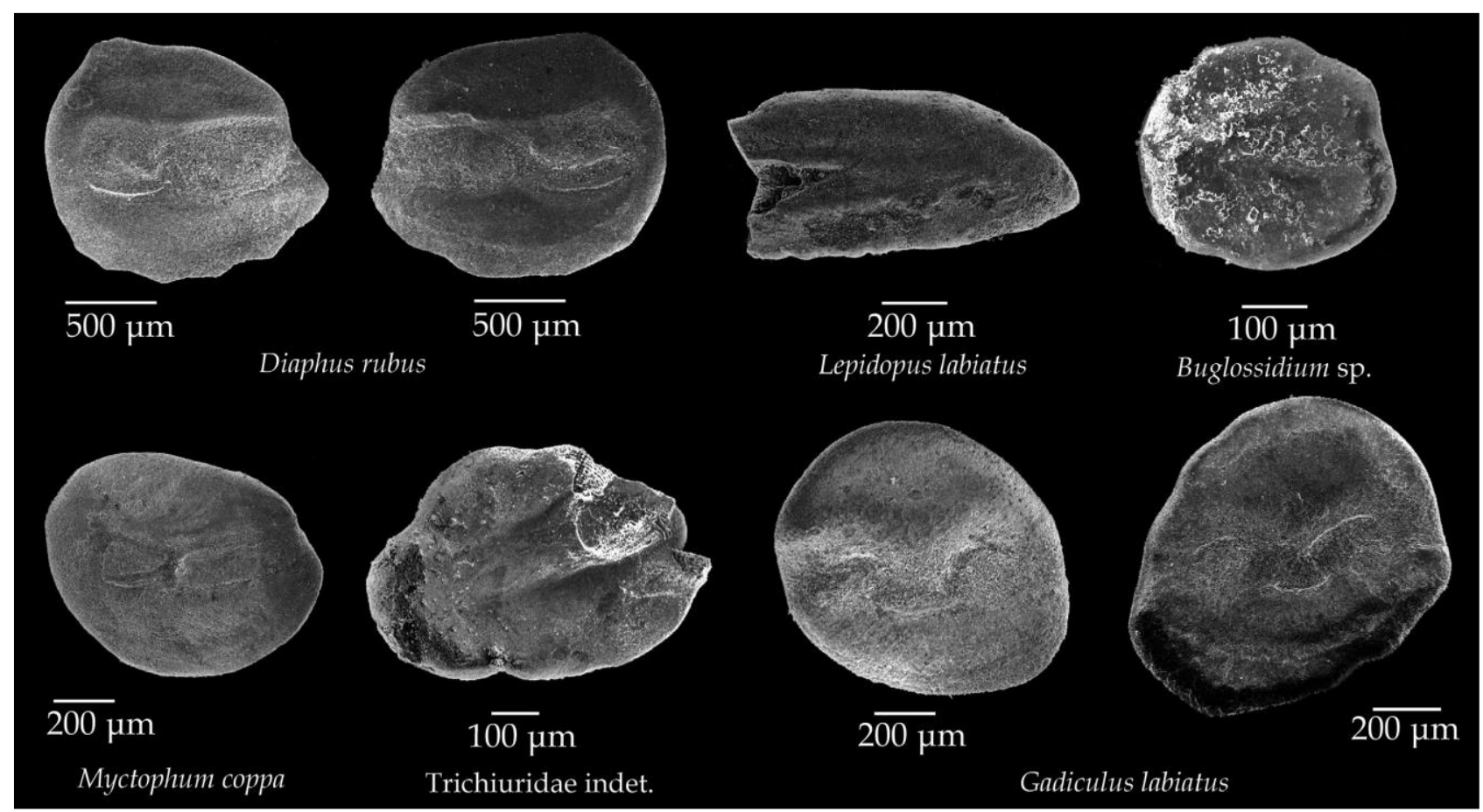

Fig. 15. Fish otoliths discovered in the pre-evaporitic sequence of Kalamaki section. 


\section{SECTION EAST \\ (Messinian/Zanclean)}

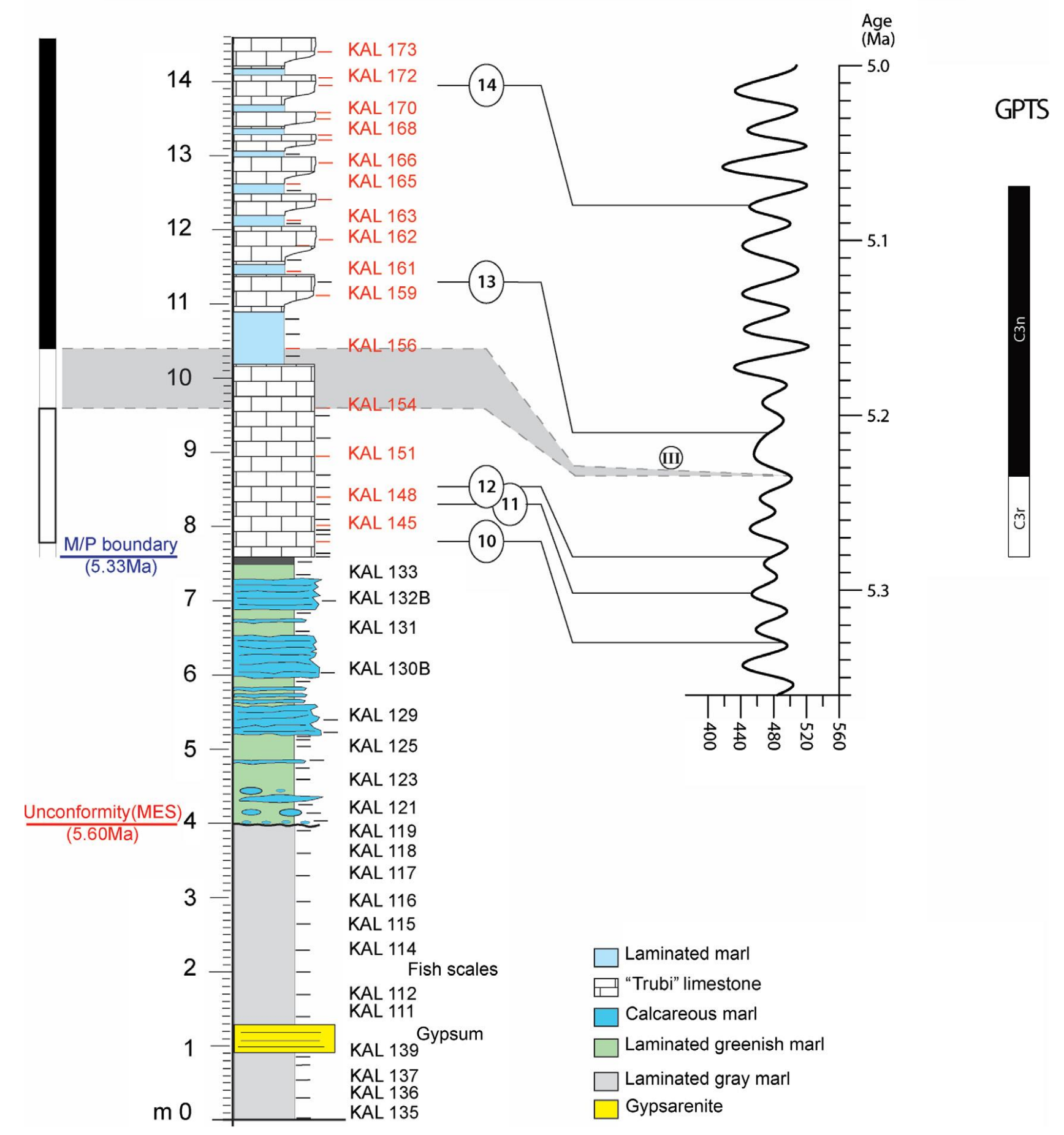

Insolation (650N)

Laskar et al., 2004

Fig. 16. Kalamaki section age model of the PLG top portion, Lago Mare, and Trubi Formation, correlated with insolation curve (based on Laskar et al., 2004). Bio-magnetostratigraphic events are as follows: 10) N. acostaensis influx sinistral; 11) Sphaeroidinellopsis spp. AB; 12) N. acostaensis influx sinistral; 13) Sphaeroidinellopsis spp. AE; 14) FCO G. margaritae; III) boundary $\mathrm{C} 3 \mathrm{r} / \mathrm{C} 3 \mathrm{n}$. (full data are available as supplementary material). 


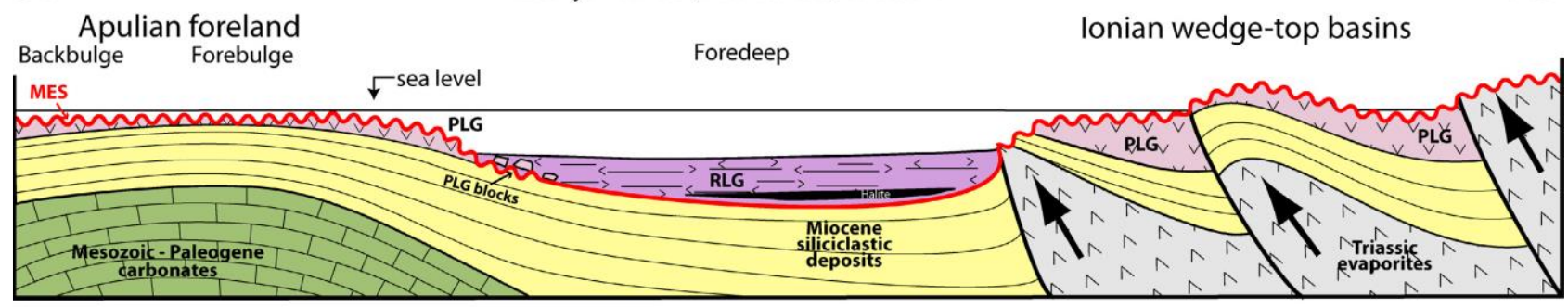

(a)

Late Messinian

Agios Sostis

Kalamaki

Argassi

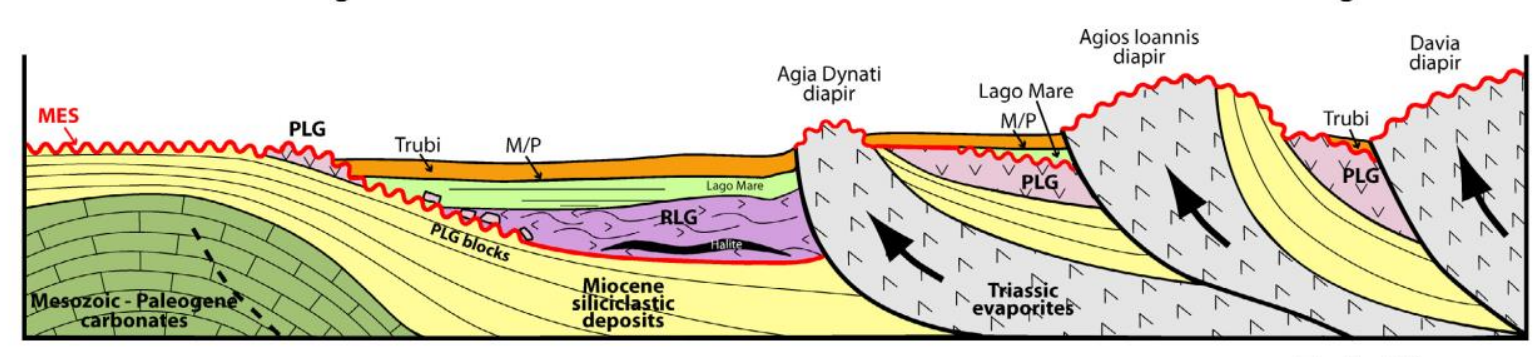

(b)

Early Pliocene

Fig. 17. Palaeogeographic reconstruction. (a) During the Messinian, the Zakynthos (Alikanas) foreland basin was formed in front of the Ionian thrust. The Neogene formations deposited over the pre-Apulian domain corresponded to the foredeep and the flank between foredeep and forebulge, whereas those overlying the Ionian zone corresponded to the wedge-top, which was uplifted due to the diapiric movements of the Ionian Triassic evaporites. In the 1st MSC stage, PLG was deposited on both forebulge and wedge-top. In the 2nd MSC stage, PLG was totally or partially eroded (creating the Messinian Erosional Surface; MES) and redeposited with correlative conformity mainly as gypsum turbidites (RLG unit) in the depocentre of the foreland basin. (b) During the end of the Messinian, in Kalamaki-Argassi wedge-top area the Lago Mare sediments were unconformably overlying the Primary Lower Gypsum above the MES, whereas in the depocentre of the foreland basin they were conformably deposited over the Resedimented Lower Gypsum. The Zanclean flood was recorded on both areas by the conformable deposition of the Trubi Formation. With red raffled and continuous line the unconformity and the correlative conformity of the MES, respectively. 